\title{
Parasite responses to pollution: what we know and where we go in 'Environmental Parasitology'
}

\author{
Bernd Sures ${ }^{1,2}$, Milen Nachev ${ }^{1 *}$, Christian Selbach ${ }^{3}$ and David J. Marcogliese $e^{4,5}$
}

\begin{abstract}
Environmental parasitology deals with the interactions between parasites and pollutants in the environment. Their sensitivity to pollutants and environmental disturbances makes many parasite taxa useful indicators of environmental health and anthropogenic impact. Over the last 20 years, three main research directions have been shown to be highly promising and relevant, namely parasites as accumulation indicators for selected pollutants, parasites as effect indicators, and the role of parasites interacting with established bioindicators. The current paper focuses on the potential use of parasites as indicators of environmental pollution and the interactions with their hosts. By reviewing some of the most recent findings in the field of environmental parasitology, we summarize the current state of the art and try to identify promising ideas for future research directions. In detail, we address the suitability of parasites as accumulation indicators and their possible application to demonstrate biological availability of pollutants; the role of parasites as pollutant sinks; the interaction between parasites and biomarkers focusing on combined effects of parasitism and pollution on the health of their hosts; and the use of parasites as indicators of contaminants and ecosystem health. Therefore, this review highlights the application of parasites as indicators at different biological scales, from the organismal to the ecosystem.
\end{abstract}

Keywords: Metal pollution, Ecosystem health, Biomarker, Ecotoxicology, Parasites, Endocrine disruption, Bioindication

\section{Background}

In recent years, research on environmental implications of parasites has seen a strong increase, leading to the establishment of 'Environmental Parasitology' (EP) as an accepted discipline covered in parasitology textbooks [1]. EP in the sense of an ecologically based approach focuses on parasites as indicators of environmental health. Occasionally, EP is also used in a medical context, especially when the contamination and occurrence of infective parasitic stages in the environment is addressed [2]. However, the current paper focuses on the function parasites may have as indicators of environmental quality. Following a number of influential reviews [3-15], many case studies were initiated to unravel possible impacts of anthropogenic changes on parasites. Among the variety of studies, the following three main research directions have been proven

\footnotetext{
* Correspondence: milen.nachev@uni-due.de

${ }^{1}$ Aquatic Ecology and Centre for Water and Environmental Research, University of Duisburg-Essen, Universitätsstr. 5, D-45141 Essen, Germany Full list of author information is available at the end of the article
}

to be most promising: (i) parasites as accumulation indicators for selected pollutants, (ii) parasites as effect indicators in the broadest sense, and (iii) parasites interfering with the health of their hosts and with established monitoring or effect studies using free-living organisms. As these research directions have frequently been reviewed in the past (e.g. $[12,13,16-18])$ we intend to summarize the most recent findings in the field of pollution associated EP and try to identify promising ideas for future research.

The use of parasites as accumulation indicators specifically addresses the questions if and how parasites can be used to indicate the biological availability of certain substances which are commonly accepted to be harmful to the environment. Based on the fact that certain groups of endoparasites are excellent accumulators of toxic metals $[12,16,19]$ and selected organic pollutants [20], one can suggest adding parasites to the list of already existing (free-living) accumulation indicators. As free-living species are usually much easier to work with than parasites, which are hidden in their hosts, good arguments are required to 
justify parasites as additional accumulation indicators. One such argument can be the proof of the biological availability of pollutants in those groups of parasites which lack a digestive system. If, for example, substances can be detected in acanthocephalans and cestodes, they had to cross through the parasites' tegument and membranes and therefore have to be biologically available. In contrast, if substances are detected in filter-feeding organisms, such as mussels, it remains unclear if the substances are only loosely attached to the gills or present in the content of the intestine instead of being taken up on a cellular level. Additionally, the accumulation of toxic substances in parasites may also have implications for pollutant levels in the host tissues. We therefore have reviewed recent studies on possible beneficial effects [21] parasites may have on their hosts.

By definition, parasites are not neutral with respect to their interaction with their hosts. They have long been recognized as important pathogens of man and livestock which resulted in a growing body of knowledge on adverse effects parasites have on their hosts. Many of these are documented in medical and veterinary text books. In recent years however a variety of molecular tools has allowed us to get a more detailed understanding of the physiological and molecular interaction of parasites with their hosts. These interactions affect the physiological homeostasis of the host, often leading to negative effects on its health. Moreover, deviations from physiological homeostasis also occur if organisms are confronted with pollutants. In the field of ecotoxicology many of these deviations are used as biological markers to indicate effects of pollutants $[17,18]$. The studies reviewed here show that unpredictable or contradictory results emerge if infected animals are used in ecotoxicological research without considering possible effects of parasites on biomarker responses.

Effect indication with parasites is a much more intricate field in EP, as it usually concentrates on complex biotic responses. In classical ecotoxicological research physiological, behavioral or molecular changes are determined as a response to adverse environmental changes, often due to the presence and effects of pollutants [22] or habitat disturbance. If parasites are considered as effect indicators, applicable approaches mainly focus on direct effects of pollutants on the viability and longevity of free-swimming stages such as cercariae or on changes in population and community structure. In the sense that parasites are integrative parts of food webs within ecosystems, environmental changes can be earmarked by parasites if one of their developmental stages or one of their hosts is negatively affected. In either situation, such adverse effects result in numerical changes of parasites, i.e. in changes of biodiversity patterns and associated indices, such as measures of diversity or the ratio between monoxenic and heteroxenic species. Once we are able to predict and calibrate such numerical changes within parasite communities depending on the type and intensity of human impacts, parasites can be powerful tools to indicate environmental changes. Recent studies on these issues are summarized and promising research ideas are presented and discussed.

In detail, we will address the following topics: (i) parasites as accumulation indicators and their possible application to demonstrate biological availability of pollutants; (ii) parasites as pollutant sinks; (iii) the interaction between parasites and biomarkers and their consequences for host health; (iv) contaminant effects on free-living stages of parasites; and (v) parasites as indicators for ecosystem health.

\section{Parasites as accumulation indicators and tools to demonstrate biological availability of pollutants}

A large number of studies have demonstrated and highlighted a high accumulation potential of different parasite taxa and identified them as useful sentinels for chemical pollution. Table 1 provides a detailed summary of studies on metal accumulation in different parasite taxa. In comparison to established free-living accumulation indicators, parasites are often able to take up chemicals (e.g. metals) at much higher levels [12, 16-19]. Thus, they can bioconcentrate pollutants which are present in very low concentrations in the environment and make them detectable and quantifiable using conventional analytical techniques. Furthermore, some parasites were found to tolerate very high pollutant burdens (see below), which suggest that they might be applicable as sentinels for polluted habitats. Moreover, since accumulation indicators provide important information about the biological availability of pollutants, parasites represent possible diagnostic tools for assessing the behaviour of chemicals in the environment and to what degree they are available for uptake by the biota.

The individual accumulation potential of various parasite taxa has been investigated in laboratory and field studies. Sures [12] summarized and listed 15 different parasite species which exhibit a high metal accumulation potential. However, the number of studies has increased rapidly in the last decade, and to date more than 50 metazoan parasite species, belonging primarily to the four major endohelminth taxa (Acanthocephala, Cestoda, Digenea and Nematoda) have been considered and suggested as sentinels for metal pollution (see Table 1). Amongst those, cestodes with about 30 different species from different hosts and habitats (limnetic, marine, terrestrial) represent the largest group, followed by nematodes, acanthocephalans and digeneans. Acanthocephalans and cestodes show the highest accumulation capacity so far, being able to accumulate different elements, especially non-essential or toxic ones, at very high levels ([12]; see also Table 1). For example, the concentrations of cadmium and lead have been shown to be up to 2,700 times higher in the acanthocephalan parasite Pomphorhynchus laevis than in its hosts' 
Table 1 Summary of the studies on metal accumulation in parasites published after the review paper of Sures [12]. Elements marked in bold were accumulated to a higher degree in the parasites than in the host tissues; ranges of bioconcentration factors with reference to host tissues were provided only for these elements

\begin{tabular}{|c|c|c|c|c|c|c|c|}
\hline Habitat & Parasite taxa & Host & Host tissue & Element & Study type & BCF range & Reference \\
\hline & Acanthocephala & & & & & & \\
\hline \multirow[t]{2}{*}{ limnetic } & Acanthocephalus anguillae & Perca fluviatilis & I & $\mathbf{A g}, \mathrm{Cd}, \mathrm{Cu}, \mathrm{Fe}, \mathbf{M n}, \mathrm{Pb}$ & field & $2.2-29.1$ & [157] \\
\hline & & Squalius cephalus & i & $\begin{array}{l}\mathrm{Ag}, \mathrm{Cd}, \mathrm{Cu}, \mathrm{Fe}, \mathrm{Mn}, \mathrm{Pb} \\
\mathrm{Zn}\end{array}$ & field & $1-29.1$ & [158] \\
\hline \multirow[t]{5}{*}{ limnetic } & Acanthocephalus lucii & Perca fluviatilis & m, l, go & $\mathrm{Pb}$ & field & $9-55$ & [159] \\
\hline & & Perca fluviatilis & $m, l, k, h r, b r$ & $\begin{array}{l}\text { As, } \mathrm{Cd}, \mathrm{Cr}, \mathrm{Cu}, \mathrm{Hg} \mathbf{M n} \\
\mathrm{Ni}, \mathrm{Pb}, \mathrm{Zn}\end{array}$ & field & $1.3-170.7$ & [160] \\
\hline & & Perca fluviatilis & m, go & $\mathrm{Hg}$ & field & $\mathrm{BCF}<1$ & [161] \\
\hline & & Perca fluviatilis & $m, l, k, h r, b r$ & $\begin{array}{l}\text { As, } \mathrm{Cd}, \mathrm{Cr}, \mathrm{Cu}, \mathrm{Hg} \mathbf{M n} \\
\mathrm{Ni} \mathbf{P b}, \mathrm{Zn}\end{array}$ & field & $1.2-370$ & [162] \\
\hline & & Perca fluviatilis & $m, l, g o$ & $\mathrm{Cd}, \mathrm{Cu}, \mathrm{Mn}, \mathrm{Zn}$ & field & $2.2-194$ & [163] \\
\hline limnetic & Acanthogyrus sp. & Oreochromis niloticus & $m, i, l$ & $\mathrm{~Pb}$ & field & $102-147$ & [164] \\
\hline \multirow[t]{2}{*}{ terrestrial } & Moniliformis moniliformis & Rattus rattus & $\mathrm{l}, \mathrm{k}$ & $\mathrm{Cd}, \mathrm{Pb}$ & field & $1.2-86.9$ & {$[35]$} \\
\hline & & "urban rat" & $m, l, k$ & $\mathrm{Cd}, \mathrm{Cr}$ & field & $4.7-17.1$ & {$[165]$} \\
\hline \multirow[t]{5}{*}{ limnetic } & Pomphorhynchus laevis & Barbus barbus & $m, i, l$ & $\begin{array}{l}\text { As, } \mathrm{Cd}, \mathrm{Co}, \mathrm{Cu}, \mathrm{Fe}, \mathrm{Mn} \\
\mathrm{Mo}, \mathrm{Ni}, \mathrm{Pb}, \mathrm{Sn}, \mathrm{V}, \mathbf{Z n}\end{array}$ & field & $1.2-1,070$ & [166] \\
\hline & & Barbus barbus & $m, i, l$ & $\begin{array}{l}\mathrm{As}, \mathrm{Cd}, \mathrm{Co}, \mathrm{Cu}, \mathrm{Fe}, \mathrm{Mn} \\
\mathrm{Pb}, \mathrm{Se}, \mathrm{Sn}, \mathrm{V}, \mathrm{Zn}\end{array}$ & field & $1.2-337$ & [27] \\
\hline & & Perca fluviatilis & 1 & $\mathbf{A g}, \mathbf{C d}, \mathbf{C u}, \mathrm{Fe}, \mathbf{M n}, \mathrm{Pb}$ & field & $1.9-57.6$ & [157] \\
\hline & & Squalius cephalus & i & $\begin{array}{l}\mathrm{Ag}, \mathrm{Cd}, \mathrm{Cu}, \mathrm{Fe}, \mathrm{Mn}, \mathrm{Pb} \\
\mathrm{Zn}\end{array}$ & field & $1.3-112.5$ & [158] \\
\hline & Cestoda & & & & & & \\
\hline marine & Anthobothrium sp. & Carcharhinus dussumieri & $m, i, l, g o$ & $\mathrm{Cd}, \mathrm{Pb}$ & field & $21.4-1,175$ & [25] \\
\hline limnetic & Bathybothrium rectangulum & Barbus barbus & $\mathrm{m}$ & $\mathrm{Cd}, \mathbf{C r}, \mathbf{N i}, \mathbf{P b}$ & field & $1.2-2.3$ & [167] \\
\hline limnetic & Bothriocephalus acheilognathi & $\begin{array}{l}\text { Labeobarbus } \\
\text { kimberleyensis }\end{array}$ & $m, l, s c$ & $\begin{array}{l}\mathrm{As}, \mathrm{Ba}, \mathbf{B e}, \mathrm{Cd}, \mathrm{Co}, \mathrm{Cr} \\
\mathrm{Cu}, \mathrm{Fe}, \mathbf{H g}, \mathrm{Li}, \mathbf{M n}, \mathrm{Mo}, \\
\mathrm{Ni}, \mathbf{P b}, \mathbf{S e}, \mathrm{Sb}, \mathrm{Sn}, \mathrm{Te}, \mathrm{Ti}, \\
\text { TI, U, V, Zn, }\end{array}$ & field & na & [168] \\
\hline limnetic & Caryophyllaeus laticeps & Chondrostoma nasus & m, i, l, gi & $\mathrm{Cd}, \mathrm{Cu}, \mathrm{Pb}, \mathrm{Zn}$ & field & $3-9.7$ & [169] \\
\hline marine & Clestobothrium crassiceps & Merluccius merluccius & $m, l, k$ & $\mathrm{As}, \mathrm{Hg}$, Se & field & $\mathrm{BCF}<1$ & [170] \\
\hline terrestrial & Gallegoide sarfaai & Apodemus sylvaticus & $m, l, k$ & $\mathrm{Cd}, \mathrm{Pb}$ & field & $6.2-24$ & [171] \\
\hline marine & Gyrocotyle plana & Callorhinchus capensis & $m, i, l, k$, go & $\begin{array}{l}\mathrm{Al}, \mathbf{A s}, \mathrm{Cd}, \mathrm{Co}, \mathrm{Cr}, \mathrm{Cu} \\
\mathbf{M n}, \mathrm{Ni}, \mathbf{P b}, \mathrm{Sb}, \mathrm{Se}, \mathrm{Sn} \\
\mathrm{Th}, \mathrm{Ti}, \mathrm{U}, \mathrm{V}, \mathbf{Z n}\end{array}$ & field & $1.1-23.4$ & {$[172]$} \\
\hline \multirow[t]{3}{*}{ terrestrial } & Hymenolepis diminuta & "urban rat" & $m, l, k$ & $\mathrm{Cd}, \mathrm{Cr}$ & field & $2.7-11.6$ & [165] \\
\hline & & Meriones libycus & $\mathrm{i}, \mathrm{l}, \mathrm{k}$ & $\mathrm{Pb}$ & field & $7.55-21.9$ & {$[173]$} \\
\hline & & Rattus norvegicus & $\begin{array}{l}\text { m, i, l, k, bo, } \\
\text { te }\end{array}$ & $\mathrm{Pb}$ & experimental & $2.6-210$ & {$[174]$} \\
\hline marine & Lacistorhynchus dollfusi & Citharichthys sordidus & $m, i, l$ & $\begin{array}{l}\mathrm{Ag}, \mathrm{As}, \mathrm{Cd}, \mathrm{Cr}, \mathrm{Cu}, \mathbf{F e} \\
\mathbf{H g}, \mathrm{K}, \mathrm{Pb}, \mathrm{Rb}, \mathrm{Se}, \mathrm{Sr}, \mathrm{Ti} \\
\mathbf{Z n}\end{array}$ & field & $1.9-117.6$ & {$[175]$} \\
\hline \multirow[t]{4}{*}{ limnetic } & Ligula intestinalis & Rastreneobola argentea & whole fish & $\mathrm{Cd}, \mathrm{Cr}, \mathrm{Cu}, \mathrm{Pb}$ & field & $2.5-18$ & {$[46]$} \\
\hline & & Tinca tinca & m, l, go & $\begin{array}{l}\mathrm{Cd}, \mathrm{Cr}, \mathrm{Cu}, \mathrm{Fe}, \mathbf{M n}, \mathbf{Z n} \\
\mathrm{Pb}\end{array}$ & field & $1.6-37.4$ & {$[176]$} \\
\hline & & Tinca tinca & I & $\begin{array}{l}\text { Al, B, Ba, Cd, Cr, Ni, Pb, } \\
\text { Sr }\end{array}$ & field & $1.2-3$ & [177] \\
\hline & & $\begin{array}{l}\text { Abramis brama, Blicca } \\
\text { bjoerkna, Rutilus rutilus }\end{array}$ & $\mathrm{m}$ & $\mathrm{Cd}, \mathrm{Cr}, \mathrm{Ni}, \mathrm{Pb}$ & field & $2.3-35.6$ & [167] \\
\hline terrestrial & Mesocestoides spp. & Vulpes vulpes & $\mathrm{l}, \mathrm{k}$ & $\mathrm{Cu}, \mathrm{Cr}, \mathrm{Mn}, \mathrm{Ni}, \mathrm{Pb}, \mathrm{Zn}$ & field & $1.9-52$ & {$[178]$} \\
\hline
\end{tabular}


Table 1 Summary of the studies on metal accumulation in parasites published after the review paper of Sures [12]. Elements marked in bold were accumulated to a higher degree in the parasites than in the host tissues; ranges of bioconcentration factors with reference to host tissues were provided only for these elements (Continued)

\begin{tabular}{|c|c|c|c|c|c|c|c|}
\hline terrestrial & Moniezia expansa & Ovis aries & $m, l, k$ & $\mathrm{~Pb}$ & experimental & $4.0-458.5$ & [179] \\
\hline terrestrial & Moniezia expansa & Ovis aries & $m, k$ & $\mathrm{Cd}$ & experimental & $1.5-31$ & [180] \\
\hline terrestrial & Mosgovoyia ctenoides & Oryctolagus cuniculus & $\mathrm{i}, \mathrm{l}, \mathrm{k}$ & As, $\mathrm{Cd}, \mathbf{P b}, \mathrm{Hg}$ & field & $1.36-2.58$ & [181] \\
\hline terrestrial & Paranoplocephala dentata & $\begin{array}{l}\text { Clethrionomys glareolus, } \\
\text { Microtus agrestris }\end{array}$ & l, k & $\begin{array}{l}\mathrm{Cd}, \mathrm{Cr}, \mathrm{Cu}, \mathbf{M n}, \mathbf{N i}, \mathbf{P b} \\
\mathbf{Z n}\end{array}$ & field & $1.7-37$ & [182] \\
\hline marine & Paraorigmatobothrium sp. & Carcharhinus dussumieri & $m, i, l, g o$ & $\mathrm{Cd}, \mathrm{Pb}$ & field & $\begin{array}{l}410- \\
1,112.9\end{array}$ & {$[25]$} \\
\hline marine & Polypocephalus sp. & Himantura cf. gerarrdi & $m, i$ & $\mathrm{Cd}, \mathrm{Pb}$ & field & $5.2-6.1$ & [183] \\
\hline limnetic & Proteocephalus macrocephalus & Anguilla anguilla & $m, l, k$ & $\begin{array}{l}\text { As, } \mathrm{Cd}, \mathbf{C r}, \mathrm{Cu}, \mathrm{Hg}, \mathbf{N i}, \\
\mathbf{P b}, \mathrm{Pd}, \mathrm{Pt}, \mathbf{Z n}\end{array}$ & field & $2.1-15.8$ & [184] \\
\hline \multirow[t]{2}{*}{ limnetic } & Proteocephalus percae & Perca fluviatilis & $m, l, k, h r, b r$ & $\begin{array}{l}\text { As, } \mathrm{Cd}, \mathbf{C r}, \mathrm{Cu}, \mathrm{Hg}, \mathbf{M n}, \\
\mathrm{Ni}, \mathbf{P b}, \mathbf{Z n}\end{array}$ & field & $1.8-149.0$ & [160] \\
\hline & & Perca fluviatilis & $m, l, k, h r, b r$ & $\begin{array}{l}\text { As, } \mathrm{Cd}, \mathrm{Cr}, \mathrm{Cu}, \mathrm{Hg}, \mathrm{Mn}, \\
\mathrm{Ni}, \mathrm{Pb}, \mathrm{Zn}\end{array}$ & field & $1.7-234$ & [162] \\
\hline terrestrial & Raillietina micracantha & Columba livia & $m, l, k, f e$ & $\begin{array}{l}\mathrm{As}, \mathrm{Cd}, \mathrm{Cr}, \mathrm{Cu}, \mathrm{Hg}, \mathrm{Mn} \\
\mathrm{Pb}, \mathrm{Se}, \mathrm{Zn}\end{array}$ & field & $6.1-79.8$ & [185] \\
\hline marine & Rhinebothrium sp. 1 & Himantura cf. gerarrdi & $m, i$ & $\mathrm{Cd}, \mathrm{Pb}$ & field & $1.2-2.5$ & [183] \\
\hline marine & Rhinebothrium sp. 2 & Glaucostegus granulatus & $m, i$ & $\mathrm{Cd}, \mathrm{Pb}$ & field & $2.4-3.7$ & [183] \\
\hline terrestrial & Rodentolepis microstoma & Mus domesticus & $m, l, k$ & $\mathrm{Cd}, \mathrm{Pb}$ & field & $1.2-60.6$ & {$[35]$} \\
\hline limnetic & Senga parva & Channa micropeltes & $m, i, l, k$ & $\mathrm{Cd}, \mathrm{Cu}, \mathbf{M n}, \mathbf{P b}, \mathbf{Z n}$ & field & na & [186] \\
\hline terrestrial & Skrjabinotaenia lobata & Apodemus sylvaticus & $m, l, k$ & $\mathrm{Cd}, \mathbf{P b}$ & field & $8.5-81.4$ & [187] \\
\hline terrestrial & Taenia taenaeiformis & "urban rat" & $m, l, k$ & $\mathrm{Cd}, \mathrm{Cr}$ & field & $2.7-11.6$ & [165] \\
\hline marine & Tatragonocephalum sp. & Himantura cf. gerarrdi & $m, i$ & $\mathrm{Cd}, \mathrm{Pb}$ & field & $1.6-1.8$ & [183] \\
\hline \multirow[t]{2}{*}{ terrestrial } & Tetrabothrius bassani & Morus bassanus & $m, l, k$ & $\begin{array}{l}\mathrm{As}, \mathrm{Cd}, \mathrm{Cr}, \mathrm{Cu}, \mathrm{Hg}, \mathrm{Mn} \\
\mathrm{Pb}, \mathrm{Se}, \mathrm{Zn}\end{array}$ & field & $6.9-9.5$ & [188] \\
\hline & Nematoda & & & & & & \\
\hline \multirow[t]{2}{*}{ limnetic } & Aguillicola crassus & Anguilla anguilla & $m, l, k$ & $\begin{array}{l}\text { As, } \mathrm{Cd}, \mathrm{Cr}, \mathrm{Cu}, \mathrm{Hg}, \mathbf{N i} \text {, } \\
\mathrm{Pb}, \mathrm{Pd}, \mathrm{Pt}, \mathrm{Zn}\end{array}$ & field & 1.31 & [184] \\
\hline & & Anguilla anguilla & $m, l, s b, s k$ & $\begin{array}{l}\mathrm{Cd}, \mathrm{Cr}, \mathrm{Cu}, \mathrm{Fe}, \mathrm{Hg}, \mathrm{Mn} \\
\mathrm{Pb}, \mathrm{Zn}\end{array}$ & field & 25.5 & [189] \\
\hline marine & Anisakis sp. & Dicentrarchus labrax & $m, l, g i$ & $\begin{array}{l}\mathrm{Cd}, \mathrm{Cu}, \mathrm{Fe}, \mathrm{Mn}, \mathrm{Ni}, \mathrm{Pb} \\
\mathrm{Zn}\end{array}$ & field & $2-16$ & [190] \\
\hline marine & Ascaris sp. & Liza vaigiensis & $m, i$ & $\mathrm{As}, \mathrm{Cd}, \mathrm{Fe}, \mathrm{Hg}, \mathrm{Pb}, \mathrm{Zn}$ & field & $26.5-400$ & [191] \\
\hline terrestrial & Contracaecum spp. & Phalacrocorax auritus & $\mathrm{m}$ & $\mathrm{Hg}$ & field & 1.4 & [192] \\
\hline limnetic & & Acestrorhynchus lacustris & $m, l$ & $\begin{array}{l}\mathrm{Al}, \mathrm{As}, \mathrm{Ba}, \mathrm{Cd}, \mathrm{Cu}, \mathrm{Cr} \\
\mathrm{Fe}, \mathrm{Mg}, \mathrm{Mn}, \mathrm{Ni}, \mathrm{Pb}, \mathrm{Ti} \\
\mathrm{Zn}\end{array}$ & field & $4.1-98.2$ & [193] \\
\hline marine & Dichelyne minutus & Chasar bathybius & $\mathrm{i}, \mathrm{l}$ & $\mathrm{Cu}, \mathrm{Zn}$ & field & 19-194 & {$[28]$} \\
\hline marine & Echinocephalus sp. & Liza vaigiensis & $m, i$ & $\mathrm{As}, \mathrm{Cd}, \mathrm{Fe}, \mathrm{Hg}, \mathrm{Pb}, \mathrm{Zn}$ & field & $20.6-360$ & [191] \\
\hline limnetic & Eustrogylides sp. & Barbus barbus & $m, i, l$ & $\begin{array}{l}\text { As, Cd, Co, Cu, Fe, Mn, } \\
\text { Pb, Se, Sn, V, Zn }\end{array}$ & field & $1.4-123$ & {$[27]$} \\
\hline marine & Hysterothylacium sp. & Trichiurus lepturus & $m, i, l, g o$ & $\mathrm{Cd}, \mathrm{Pb}$ & field & $1.4-1,173.5$ & [194] \\
\hline \multirow[t]{3}{*}{ marine } & Hysterothylacium aduncum & Pagellus erythrinus & $m, i, l, s b, s k$ & $\begin{array}{l}\mathrm{Cd}, \mathbf{C r}, \mathrm{Cu}, \mathrm{Fe}, \mathbf{H g}, \mathrm{Mg} \\
\mathrm{Mn}, \mathbf{P b}, \mathrm{Zn}\end{array}$ & field & $1.1-113.9$ & [195] \\
\hline & & Sparus aurata & $m, i, l, g i, s k$ & $\begin{array}{l}\mathrm{Cd}, \mathrm{Cr}, \mathrm{Cu}, \mathrm{Fe}, \mathrm{Hg}, \mathrm{Mg} \\
\mathrm{Mn}, \mathrm{Pb}, \mathrm{Zn}\end{array}$ & field & $1.63-7.31$ & [196] \\
\hline & & Solea solea & $m, l, g i, k$ & $\mathrm{Cd}, \mathrm{Cu}, \mathrm{Fe}, \mathrm{Ni}, \mathrm{Pb}, \mathrm{Zn}$ & field & $1.27-80$ & [197] \\
\hline
\end{tabular}


Table 1 Summary of the studies on metal accumulation in parasites published after the review paper of Sures [12]. Elements marked in bold were accumulated to a higher degree in the parasites than in the host tissues; ranges of bioconcentration factors with reference to host tissues were provided only for these elements (Continued)

\begin{tabular}{|c|c|c|c|c|c|c|c|}
\hline marine & Hysterothylacium reliquens & Nemipterus peronii & $m, l, k$ & $\begin{array}{l}\mathrm{Al}, \mathrm{As}, \mathrm{Cd}, \mathrm{Cr}, \mathrm{Cu}, \mathrm{Fe} \\
\mathrm{Hg}, \mathrm{Mn}, \mathrm{Ni}, \mathrm{Pb}, \mathrm{Se}, \mathrm{Sr} \\
\mathrm{Zn}\end{array}$ & field & $1.6-185$ & [198] \\
\hline marine & Paraphilometroides nemipteri & Nemipterus peronii & $m, l, k$ & $\begin{array}{l}\mathrm{Al}, \mathrm{As}, \mathrm{Cd}, \mathrm{Cr}, \mathrm{Cu}, \mathrm{Fe} \\
\mathrm{Hg}, \mathrm{Mn}, \mathrm{Ni}, \mathrm{Pb}, \mathrm{Se}, \mathrm{Sr}, \mathrm{Zn}\end{array}$ & field & $1-1,861.2$ & [198] \\
\hline limnetic & Philometra ovata & Gobio gobio & $\mathrm{m}$ & $\mathrm{Cd}, \mathrm{Cr}, \mathrm{Cu}, \mathrm{Pb}, \mathrm{Ni}, \mathrm{Zn}$ & field & $3.2-121.7$ & [199] \\
\hline limnetic & Procamallanus spp. & Synodontis clarias & i & $\mathrm{Cd}, \mathrm{Fe}, \mathrm{Mn}, \mathrm{Pb}, \mathrm{Zn}$ & field & $1.4-22.2$ & [200] \\
\hline marine & Proleptus obtusus & $\begin{array}{l}\text { Rhinobatos annulatus, } \\
\text { Rhinobatos blochii }\end{array}$ & $m, i, l, k, g o$ & $\begin{array}{l}\mathrm{Al}, \mathrm{As}, \mathrm{Cd}, \mathrm{Co}, \mathrm{Cr}, \mathrm{Cu}, \\
\mathrm{Mn}, \mathrm{Ni}, \mathrm{Pb}, \mathrm{Sb}, \mathrm{Se}, \mathrm{Sn}, \\
\mathrm{Th}, \mathrm{Ti}, \mathrm{U}, \mathrm{V}, \mathrm{Zn}\end{array}$ & field & $\mathrm{BCF}<1$ & [172] \\
\hline terrestrial & Toxascaris leonina & Vulpes vulpes & $\mathrm{l}, \mathrm{k}$ & $\mathrm{Cu}, \mathrm{Cr}, \mathrm{Mn}, \mathbf{N i}, \mathbf{P b}, \mathbf{Z n}$ & field & $1.2-7.7$ & [178] \\
\hline \multirow[t]{2}{*}{ terrestrial } & $\begin{array}{l}\text { Brevimulticaecum tenuicolle, } \\
\text { Dujardinascaris waltoni, } \\
\text { Eustrongylides sp., Goezia sp., } \\
\text { Ortleppascaris antipini, } \\
\text { Terranova lanceolata }\end{array}$ & Alligator mississippiensis & I & $\begin{array}{l}\text { As, } \mathbf{C d}, \mathbf{C u}, \mathrm{Fe}, \mathrm{Pb}, \mathrm{Se}, \\
\mathrm{Zn}\end{array}$ & field & $1-102$ & {$[30]$} \\
\hline & Digenea & & & & & & \\
\hline terrestrial & Drepanocephalus spathans & Phalacrocorax auritus & $\mathrm{m}$ & $\mathrm{Hg}$ & field & 1.3 & [192] \\
\hline terrestrial & Fasciola gigantica & buffaloes & $m, l$ & $\mathrm{Cd}, \mathrm{Cr}, \mathbf{C u}, \mathbf{P b}, \mathrm{Zn}$ & field & $1.5-4.7$ & {$[31]$} \\
\hline terrestrial & Fasciola hepatica & buffaloes & $m, l$ & $\mathrm{Cd}, \mathrm{Cr}, \mathrm{Cu}, \mathbf{P b}, \mathrm{Zn}$ & field & $1.8-3.6$ & {$[31]$} \\
\hline marine & Neoapocreadium chabaudi & Balistes capriscus & $m, l, k$ & $\mathrm{Se}, \mathrm{Hg}$ & field & $\mathrm{BCF}<1$ & [201] \\
\hline marine & Robphildollfusium fractum & Sarpa salpa & $m, l, k$ & $\mathrm{Se}, \mathrm{Hg}$ & field & $1.2-7.15$ & [201] \\
\hline limnetic & Siphodera spp. & Chrysichthys nigrodigitatus & i & $\mathrm{Cd}, \mathrm{Fe}, \mathrm{Mn}, \mathrm{Pb}, \mathbf{Z n}$ & field & 1.2 & [200] \\
\hline \multirow[t]{2}{*}{ terrestrial } & $\begin{array}{l}\text { Acanthostomum pavidum, } \\
\text { Archaeodiplostomum } \\
\text { acetabulata, Protocaecum } \\
\text { coronarium, Pseudocrocodilicola } \\
\text { georgiana, P. americana, } \\
\text { Timoniella loosi }\end{array}$ & Alligator mississippiensis & I & $\begin{array}{l}\text { As, } \mathrm{Cd}, \mathrm{Cu}, \mathrm{Fe}, \mathrm{Pb}, \mathrm{Se}, \\
\mathrm{Zn}\end{array}$ & field & $1-1,154$ & {$[30]$} \\
\hline & Monogenea & & & & & & \\
\hline \multirow[t]{2}{*}{ limnetic } & Ancyrocephalus mogurndae & Siniperca chuatsi & $m, l, k$, gi & $\mathrm{Pb}$ & field & na & {$[34]$} \\
\hline & Pentastomida & & & & & & \\
\hline terrestrial & Sabekia mississippiensis & Alligator mississippiensis & I & $\begin{array}{l}\text { As, } \mathrm{Cd}, \mathbf{C u}, \mathrm{Fe}, \mathrm{Pb}, \mathbf{S e}, \\
\mathbf{Z n}\end{array}$ & field & $3-399$ & {$[30]$} \\
\hline
\end{tabular}

Abbreviations: BCF bioconcentration factors, bo bones, $b r$ brain, fe feathers, gi gills, go gonads, $h r$ hard roe, $i$ intestine, $k$ kidney, $l$ liver, $m$ muscle, na data not available, sb swimbladder, sc spinal cord, sk skin, te testes

muscle tissues [23, 24]. Similarly, high levels of these elements were also reported from cestodes, where their concentrations were up to 1,175 times higher compared to host tissues ([25]; see Table 1). Recent studies also demonstrated that cestodes are able to accumulate organic pollutants such as polychlorinated biphenyls (PCB) to a higher degree than their hosts [26]. Elevated levels of different elements were also reported for nematodes, which however mainly accumulate essential elements rather than toxic ones [27, 28]. Accordingly, organisms which take up their nutrients via their tegument, such as acanthocephalans and cestodes, appear to be more appropriate sentinels for toxic elements than other parasite taxa which have a gastro-intestinal tract. Laboratory studies on the accumulation of lead suggest that acanthocephalans take up the metal in the form of bile-metal complexes [21]. When exposed to metals, organometallic complexes are formed in the liver of many vertebrate species which then pass down the bile duct into the small intestine where they can either be reabsorbed by the intestinal wall and run through the hepatic-intestinal cycle or they can be excreted with the faeces (see [21] and references therein). If organisms are infected with acanthocephalans the parasites interrupt the hepatic-intestinal cycling of metals, as they were shown to rely on the uptake of bile acids from their host's intestine [21, 29]. In principle, all substances entering acanthocephalans and cestodes have to pass through their tegument. Accordingly, if substances can be detected in cestodes and acanthocephalans they are biologically available in the sense that they are able to 
cross biological membranes. Additionally, the parasite's localization in the host as well as its developmental stage might play an important role in the accumulation process, as the availability of metals differ within the host, and larval parasites exhibit differences in physiology and metabolism in comparison to their adult stages [27, 30].

Studies on the accumulation potential of digeneans are limited and only few species have been investigated to date. However, some species showed a high accumulation capacity [30-32] and an elevated resistance to toxic elements [33], which suggests their possible use as potential sentinels for metal pollution. Interestingly, pentastomids from reptiles also indicate a high accumulation of some essential and non-essential elements [30]. However, published data on this group as well as on Monogenea [34] is still very limited (see Table 1).

Because acanthocephalans, cestodes, nematodes and digeneans are mainly endoparasites without direct contact to the ambient environment, they have access to pollutants through their hosts. As suggested by Sures \& Siddall [21], the uptake of metals in a fish-parasite system from freshwater habitats occurs mainly over gills, circulatory system and entero-hepatic circulation of the host. In this way the metals become available for the parasites located in the intestine and other microhabitats within the host. In marine ecosystems, the dietary uptake as well as the uptake from water needed for osmoregulation seem to represent the main sources for metals [19]. Similarly, in terrestrial ecosystems the dietary uptake route of metals is more important than the direct accumulation from ambient environment (e.g. air). Thus, acanthocephalans, cestodes as well as trematodes of terrestrial mammals were also found to accumulate metals in high concentrations in a similar manner as various aquatic parasites [31, 35-37].

Acanthocephalans, cestodes and some nematodes fulfill most of the criteria required for sentinels as suggested by Sures [12]. Most species studied exhibit a high accumulation potential and high resistance to metal pollution (Table 1). Furthermore, most of the species are large in body size, widespread and very abundant in their host and can be easily sampled and identified. Most importantly, pollutant levels in parasites usually correspond to those in the environment. In contrast, other parasite taxa (e.g. monogeneans or different protozoans) do not fulfill some of the main criteria for accumulation indicators. Parasitic protozoans as well as many digeneans and monogeneans are small in size and therefore cannot provide sufficient material for chemical analyses. This might explain the limited (Monogenea, Digenea) information regarding their accumulation potential. However, among the latter group there are also species with larger body sizes and high abundance. Given that high metal accumulation rates were occasionally shown in digeneans (e.g. [30-32]), larger species should be studied more intensively in the future. Due to the direct contact with the ambient environment monogeneans can probably rapidly access and accumulate pollutants and may provide a useful tool if they are large enough.

The use of parasites as additional accumulation indicators requires good arguments in order to compete with the established free-living sentinels, which are much easier to work with. One such argument can be the remarkable accumulation capacity of parasites, as discussed above. Thus, with their help even very low environmental concentrations can be detected and quantified in relatively unpolluted habitats such as the Antarctic (e.g. [38]). Furthermore, sensitive monitoring tools will also be necessary to detect elements with very low natural abundance, such as the technologycritical elements (TCE), which are used in increasing amounts for new technologies. These elements are emitted into the environment through anthropogenic activities, although their environmental behaviour remains largely unclear [39]. Acanthocephalans, for example, are able to accumulate such elements (e.g. Pt, Pd, Rh) at levels above the detection limits of conventional analytic techniques [40]. Furthermore, acanthocephalans and cestodes can be promising organisms for studies addressing the availability of (nano-) particles. If accumulation of elements that were initially in a particulate form occurs in acanthocephalans and/or cestodes, it is necessary that they had to cross several biological membranes [40, 41]. When using filterfeeding organisms such as mussels to study the uptake of particulate elements, it remains unclear if these elements are only adsorbed at the gill filaments or present in the gut content, or if they are really taken up in a biological sense [42]. Parasites could help to close this gap and give a better understanding of the biological availability of pollutants in ecosystems.

\section{Parasites as pollutant sinks}

The enormous accumulation of pollutants in certain parasites can affect the pollutant metabolism of their hosts, as was shown as early as 1996 and 1999 [21, 43, 44]. Using experimental infections and a laboratory exposure experiment with lead, Sures \& Siddall [21] reported for the first time that chub infected with the acanthocephalan Pomphorhynchus laevis exhibited lower lead concentrations than uninfected conspecifics. This result was confirmed subsequently using the lead isotope ${ }^{210} \mathrm{~Pb}$ [45]. Likewise, Gabrashanska \& Nedeva [43] as well as Turcekova \& Hanzelova [44] reported lower metal concentrations in wild fish infected with cestodes compared with uninfected animals. Lower metal levels in acanthocephalan-infected fish were attributed to disturbance of the entero-hepatic cycling of lead within the fish host by the parasite [21]. Successively, a number of studies from different hostparasite systems was published which also showed reduced metal concentrations in tissues of infected hosts from aquatic as well as terrestrial habitats (Table 2). 
Table 2 Selected studies describing the effects of parasites on element levels in infected hosts compared to uninfected conspecifics

\begin{tabular}{|c|c|c|c|c|c|c|}
\hline Habitat & Parasite taxa & Host & $\begin{array}{l}\text { Element levels in infected } \\
\text { vs uninfected hosts }\end{array}$ & Element & Study type & Reference \\
\hline & Acanthocephala & & & & & \\
\hline \multirow[t]{3}{*}{ limnetic } & Pomphorhynchus laevis & Squalius cephalus & decrease & $\mathrm{Pb}$ & experimental & [11] \\
\hline & & Squalius cephalus & decrease & $\mathrm{Pb}$ & experimental & {$[45]$} \\
\hline & & Squalius cephalus & decrease & $\mathrm{Cd}, \mathrm{Cu}, \mathrm{Pb}$ & field & {$[157]$} \\
\hline limnetic & Acanthocephalus anguillae & Squalius cephalus & decrease & $\mathrm{Cd}, \mathrm{Cu}, \mathrm{Pb}$ & field & [157] \\
\hline limnetic & Polymorphus minutus & Gammarus roeseli & decrease & $\mathrm{Cd}$ & experimental & {$[87]$} \\
\hline limnetic & Acanthocephalus lucii & Perca fluviatilis & decrease & $\mathrm{Cr}, \mathrm{Mn}$ & field & [162] \\
\hline \multirow[t]{2}{*}{ limnetic } & Acanthogyrus sp. & Oreochromis niloticus & decrease & $\mathrm{Pb}$ & field & {$[164]$} \\
\hline & Cestoda & & & & & \\
\hline limnetic & Bothriocephalus acheilognathi & Cyclops strenuus & decrease & $\mathrm{Cd}$ & experimental & {$[115]$} \\
\hline limnetic & Bathybothrium rectangulum & Barbus barbus & decrease & $\mathrm{Cr}, \mathrm{Ni}, \mathrm{Pb}$ & field & {$[167]$} \\
\hline \multirow[t]{3}{*}{ limnetic } & Ligula intestinalis & Alburnus alburnus & decrease & $\mathrm{Cu}, \mathrm{Zn}$ & field & [43] \\
\hline & & Rastrineobola argentea & decrease & $\mathrm{Cu}$ & field & [46] \\
\hline & & Rastrineobola argentea & increase & $\mathrm{Cd}, \mathrm{Cr}, \mathrm{Zn}$ & field & [46] \\
\hline limnetic & Proteocephalus macrocephalus & Anguilla anguilla & decrease & $\mathrm{Cr}, \mathrm{Ni}$ & field & [184] \\
\hline limnetic & Proteocephalus percae & Perca fluviatilis & decrease & As, Cd & field & [44] \\
\hline limnetic & Proteocephalus percae & Perca fluviatilis & decrease & $\mathrm{Pb}$ & field & [162] \\
\hline limnetic & Proteocephalus percae & Perca fluviatilis & decrease & $\mathrm{Cr}, \mathrm{Mn}$ & field & [162] \\
\hline marine & Clestobothrium crassiceps & Merluccius merluccius & decrease & $\mathrm{As}, \mathrm{Cd}, \mathrm{Hg}, \mathrm{Pb}$ & field & {$[170]$} \\
\hline terrestrial & Mesocestoides spp. & Vulpes vulpes & decrease & $\mathrm{Pb}$ & field & {$[178]$} \\
\hline terrestrial & Mesocestoides spp. & Vulpes vulpes & increase & $\mathrm{Cu}, \mathrm{Mn}$ & field & {$[178]$} \\
\hline terrestrial & Moniezia expansa & Ovis aries & decrease & $\mathrm{Pb}$ & experimental & [179] \\
\hline terrestrial & Hymenolepis diminuta & Rattus norvegicus & decrease & $\mathrm{Cd}, \mathrm{Zn}$ & experimental & [202] \\
\hline \multirow[t]{2}{*}{ terrestrial } & Unidentified cestodes & Sterna paradisaea & decrease & $\mathrm{Bi}$ & field & {$[203]$} \\
\hline & Nematoda & & & & & \\
\hline terrestrial & Toxascaris leonina & Vulpes vulpes & decrease & $\mathrm{Pb}$ & field & {$[178]$} \\
\hline limnetic & Raphidascaris acus & Oncorhynchus mykiss & decrease & Se & experimental & {$[204]$} \\
\hline \multirow[t]{2}{*}{ estuarine } & Eustrongylides sp. & Fundulus heteroclitus & decrease & $\mathrm{Hg}$ & field & {$[205]$} \\
\hline & Digenea & & & & & \\
\hline \multirow[t]{2}{*}{ limnetic } & Different digeneans & Littorina littorea & decrease & $\mathrm{Cu}, \mathrm{Fe}, \mathrm{Ni}, \mathrm{Pb}$ & field & {$[206]$} \\
\hline & Isopoda & & & & & \\
\hline estuarine & Probopyrus pandalicola & Palaemonetes pugio & decrease & $\mathrm{Hg}$ & field & {$[205]$} \\
\hline
\end{tabular}

However, contrasting results, where the presence of parasites can increase pollutant burdens in infected hosts, have been described for some host-parasite systems (Table 2). Even if the collection of studies in Table 2 is not complete, it is evident that many cestodes and all investigated acanthocephalans are able to reduce metal levels in different tissues of their hosts. Reasons why the concentrations of the same element were differently affected by Ligula intestinalis remain unclear, but may be attributed to the fact that different fish hosts and different elements were studied [46]. It also becomes obvious that there is a strong need for more studies considering possible effects of nematodes and digeneans, as these groups are still understudied in this respect.

A possible reduction of pollutant concentrations in infected hosts has important implications. Pollutant accumulation in organisms can be assumed to result from a balance of different uptake and loss mechanisms depending on the infection status. The uptake by parasites has to be considered as an efflux from the fish host, similar to elimination [47] and can therefore directly reduce the steady state concentration of the host (Fig. 1). If animals are sampled from the field for environmental monitoring programs, pollutant levels in infected hosts 


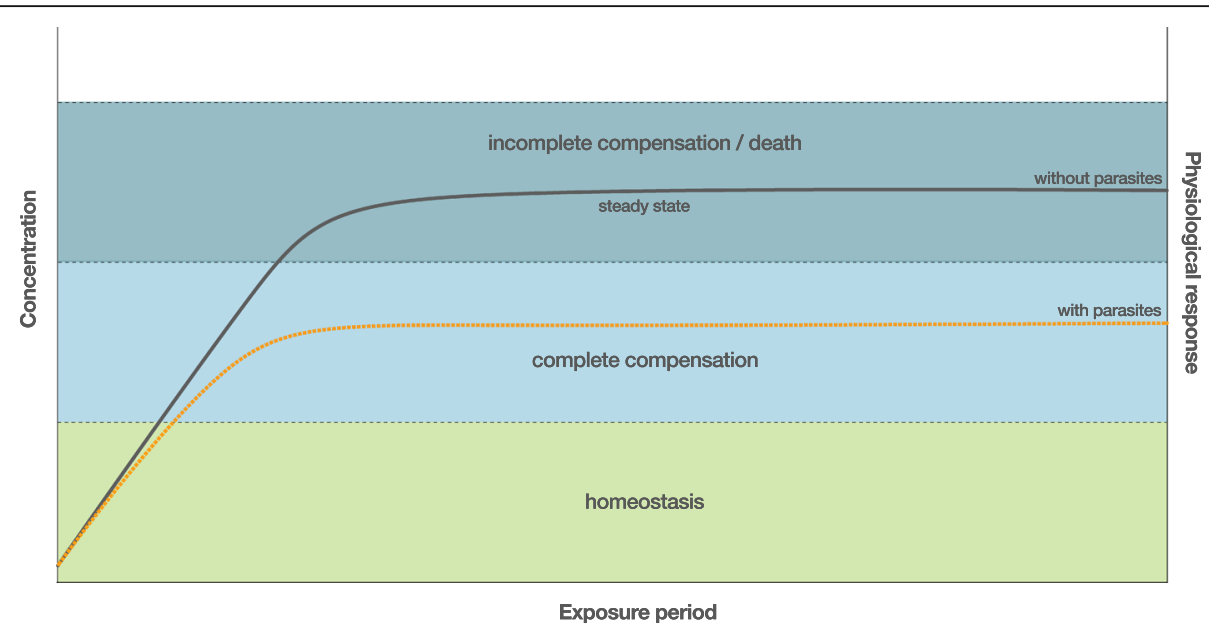

Fig. 1 Accumulation kinetics showing the concentration of a toxic substance in tissues of infected and uninfected hosts. At the steady state concentration, the uptake and elimination rates of the substance are balanced. The accumulation of toxic substances is associated with the physiological response of the exposed organism, i.e. at lower tissue concentrations physiological responses allow for a complete compensation of adverse effects. Thus, if the level of the steady state concentration is reduced due to parasitism, less severe toxic effects can be expected for the host compared to uninfected conspecifics

can thus be lower compared to uninfected specimens. If data from infected and uninfected animals are not separated, there will be a high degree of variation. If, on the other hand, mainly infected organisms are analysed, pollutant concentrations in a given habitat are probably underestimated due to parasite-reduced tissue concentrations. This highlights the need to consider the complete host-parasite system, rather than just the host (or the parasite) alone, for such monitoring and pollution assessments. An interesting question for future research would be the ecosystem relevance of pollutant accumulation in parasites. The question arises if and how parasites alter pollutant dynamics within food webs and how this affects the health of the interacting organisms.

\section{Parasite effects on biomarkers and host physiology}

Physiological responses of organisms to pollutants are a consequence of the uptake and accumulation of toxic substances (Fig. 1). The variety of responses ranges from an increased level of stress and protective molecules to a complete breakdown of physiological homeostasis and death of the exposed organism. A common approach in ecotoxicology is to use responses on a biochemical or molecular level as early warning signs to indicate the presence of contaminants and to unravel possible adverse effects on organisms [48, 49]. These responses, commonly defined as biomarkers, are analysed in environmental monitoring programs using different free living animals, such as molluscs (e.g. [50]), crustaceans (e.g. [51]) and fish (e.g. [52]), amongst others. The most commonly used biomarkers refer to measures of oxidative stress, hormone regulation, energy budgets, as well as genes and proteins involved in pollutant metabolism and excretion. Accordingly, these biomarkers are usually not a specific response to pollutants but might rather be induced by a variety of other stressors, including parasites $[17,53]$. Additionally, contaminant specific markers are used for monitoring, which indicate the presence and effects of specific pollutants, such as metallothioneins as markers for metals [54], or the induction of cytochrome P4501A that is used as a specific biomarker for exposure in fish to aryl hydrocarbon receptor (AhR) agonists such as polycyclic aromatic hydrocarbons (PAHs), pesticides and polychlorinated biphenyls (PCBs) [52]. Under environmental conditions, however, organisms are not only exposed to pollutants but are also confronted with a variety of other endogenous and exogenous factors (Fig. 2). Accordingly, the extent to which biomarkers are able to provide unambiguous and ecologically relevant indication of exposure to or effects of toxicants remains highly controversial [49]. Forbes et al. [49] therefore stressed that biomarkers may most successfully be used for hypothesis generation in controlled experiments and that more efforts are needed to develop models of appropriate complexity that can describe realworld systems at multiple scales in order to apply the biomarker concept under field conditions.

There has been an increasing awareness in recent years that parasites strongly interact with pollutantinduced biomarker responses of their hosts by influencing their physiology in a multitude of different ways. There are two main approaches, the first being experimental exposure to contaminants and parasites in the laboratory, and the second being measurement of biomarker responses in fish infected with differing 


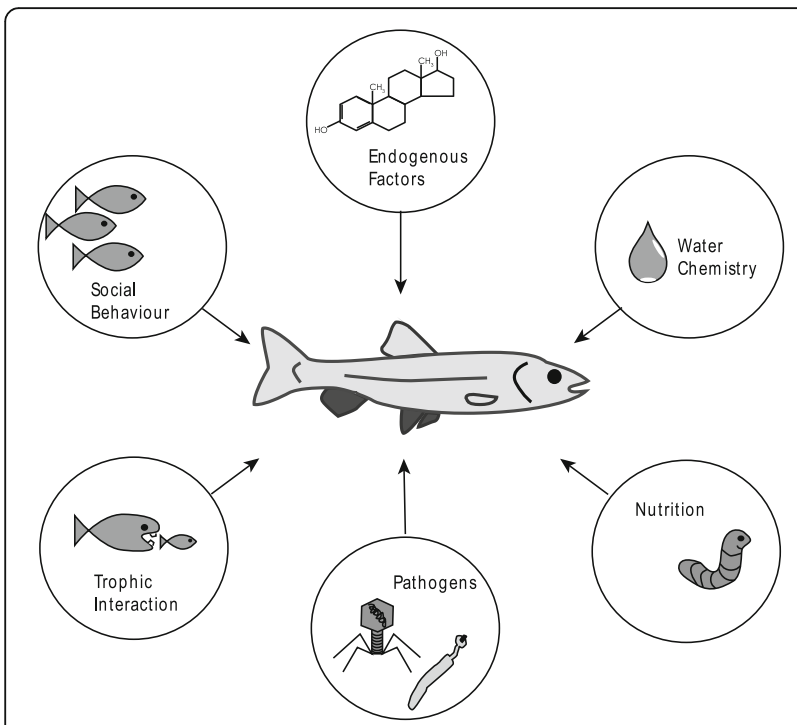

Fig. 2 Physiology, biochemistry and behaviour of organisms is affected by various internal and external parameters (drawing by Dr. Nadine Ruchter). Citation: Sures B, et al. [207] Biological effects of PGE on aquatic organisms. In: Zerein F, Wiseman CLS, editors. Platinum metals in the environment. Heidelberg: Springer Berlin Heidelberg; pp. 383-399. With permission of Springer

numbers of parasites from both polluted and reference conditions [53]. As it is not possible to review all the studies investigating combined effects of pollutants and parasites on physiological responses of their hosts (but see [53, 55-57]), examples of recent studies highlight the main categories of results usually described. The studies vary depending on the parasite and host species chosen as well as on the pollutant investigated [53, 56], and the outcome of a parasite-pollution interaction would either lead to reduced (e.g. [58]) or increased levels of biomarkers (e.g. [59]). These interactions have two main important implications: they affect the reliability of biomarkers as a diagnostic tool to determine the presence and effects of pollutants [53]; and they are the physiological basis for possible adverse effects on the hosts [56]. Both aspects are briefly summarized below. In general, the prediction can be made that larval parasites in intermediate hosts requiring trophic interactions for transmission should be more virulent [60] and thus lead to increased pathology in combination with contaminant stressors.

Modulation of biomarker responses in organisms being simultaneously infected with parasites and exposed to environmental pollutants is a phenomenon which is currently not well understood and which deserves further investigation. In certain cases, a biomarker response may increase or decrease, making interpretation difficult. For example, with biomarkers of oxidative stress it is advisable to use several enzymes and substrates involved in oxidative stress metabolism as well as pathological endpoints to better understand the stress response and physiological effect on the host [61]. Markers of energy metabolism such as total lipid and glycogen content were also shown to be differentially modulated by parasitism. Although no effect on glycogen levels due to $\mathrm{Cd}$ exposure were detected in uninfected gammarids, infection with microsporidians led to higher glycogen concentrations [62, 63]. Levels of heat-shock proteins (HSP) as indication of a general stress response in organisms are usually increased due to pollutants but may be significantly reduced when exposed gammarids are infected with acanthocephalans [58, 64]. In contrast, microsporidian infections may lead to a pronounced heat shock response [63]. Also, pollutant-specific markers such as metallothioneins (MT) were found to be sensitive to modulation by parasites. Digenean parasites in $\mathrm{Cd}$ exposed cockles lead to a decrease in MT concentrations compared to uninfected individuals $[65,66]$.

Moreover, it appears that effects commonly considered to result from environmental pollution can partly be attributed to parasites. Anthropogenic endocrine active compounds present in surface waters are an example of major environmental concern due to their potential health effects on the reproductive system in aquatic vertebrates [67, 68]. In addition to chemicals, infection with parasites can also affect the development of gonads in different groups of animals, such as crustaceans and fish (e.g. [69-73]). The most intensively studied model organism with respect to its effects on host's gonad development and the reproductive status is the larval cestode Ligula intestinalis. Infection of fish with $L$. intestinalis has long been known to inhibit reproduction in this second intermediate host $[74,75]$. It was demonstrated that inhibition of gametogenesis in infected roach (Rutilus rutilus) was accompanied by a pronounced disruption of the hypothalamus-pituitary-gonad (HPG) axis, which is the prime endocrine system regulating reproduction [76-79]. With respect to possible biomarkers it was shown that plasma concentrations of sex-steroids as well as the expression of gonadotropins in the pituitary were lower in infected fish than in uninfected [76-78]. This example shows that endocrine disruption of reproductive biology in fish is not only caused by natural and synthetic substances but also by naturally occurring parasite infections. However, the degree to which parasitism contributes to endocrine disrupting phenomena of wildlife remains unknown and therefore deserves further investigations.

This collection of examples shows that parasites might modulate the expression of various biomarkers. If such biomarkers are analysed as part of monitoring programs to identify environmental pollution, false-negative as well as false-positive results can be obtained. In addition, laboratory assays using biomarkers are typically 
performed with uninfected hosts, so extrapolation of effects to natural conditions where most animals are parasitized is problematic and underestimates the actual severity of polluted conditions [53]. Accordingly, manipulation of biomarker response by parasites easily leads to misinterpretation of pollution scenarios, if parasitism is not considered. We therefore have to get a more detailed picture of the interaction between parasites and pollutants, which means that research in this field of EP has to be intensified. Furthermore, in most study systems, there has not been strong corroboration between field and laboratory results [57]. Additionally, an increased use of modern "omic"-techniques would probably help in getting a more detailed and mechanistic understanding of the possible interactions.

The variety of interactions between parasites and pollutants may also directly affect the health of the host in different ways $[17,18,53,55,56]$. For example, several environmental pollutants may suppress the immune response of organisms, thereby leading to higher parasite infection intensities (e.g. [53, 55, 56, 80, 81]; see also chapter below). On the other hand, parasites themselves may also change the physiological or biochemical response of the host to a pollutant in different directions as both stressors might interact in a synergistically, antagonistically or additive way [53, 56, 82]. Accordingly, the health of organisms simultaneously confronted with parasites and pollutants can be more or less seriously threatened as compared to confrontation with either stressor alone [53]. However, some contrary cases have also been reported in which parasites appear to be beneficial to their host. In the following, a selected number of representative studies will be presented that are suitable to represent the variety of results that can be expected.

From a theoretical point of view, one would expect less severe effects if the steady state concentration of a pollutant in an exposed organism is reduced, e.g. due to parasites as shown by the examples listed in Table 2 . Additionally, a reduced toxicity might also result if other physiological pathways are triggered by parasites that lead to changes of the host's pollutant metabolism. In fact, a couple of studies have shown positive effects of parasites on selected life parameters. Recently, Sánchez et al. [83] demonstrated that parasites can increase host resistance to arsenic. In acute toxicity tests using Artemia parthenogenetica infected with the larval cestode species Flamingolepis liguloides and Confluaria podicipina infection consistently reduced mortality across a range of arsenic concentrations and at different temperatures. Infected $A$. parthenogenetica had higher levels of antioxidant enzymes as well as a higher number of carotenoid-rich lipid droplets, both of which help to reduce oxidative stress. Heinonen et al. [84] showed that freshwater clams, Pisidium amnicum, infected with digenean trematode larvae were less sensitive to pentachlorophenol (PCP) and survived longer than uninfected conspecifics. However, it should be mentioned that even if infected clams were able to survive longer under exposure conditions than uninfected conspecifics, they cannot reproduce due to the castrating effects of the digeneans. From a fitness' point of view, the prolonged survival of infected molluscs is therefore of no advantage for the host. In general, it remains an interesting question, why parasites lower their hosts' toxic burdens. From an evolutionary perspective, this seemingly altruistic behaviour towards their host could have developed as a strategy to keep the host alive under stressful conditions, as the demise of the host also interrupts the parasite life-cycle.

Exposure experiments have been conducted in gammarids infected with different acanthocephalan larvae with equivocal results. Until recently, it was commonly accepted that gammarids infected with acanthocephalan larvae, mainly Pomphorhynchus laevis and Polymorphus minutus, suffer more during exposure studies with metals than uninfected individuals (e.g. $[58,85,86]$ ). However, Gismondi et al. [87] presented results which suggest that infections with $P$. minutus could be advantageous for Gammarus roeseli during $\mathrm{Cd}$ exposure. When studying sex-specific lethality of $\mathrm{Cd}, \mathrm{LC}_{50}$ values revealed that infected $G$. roeseli males showed lower mortality under cadmium stress than uninfected ones. The opposite result, however, was found for female gammarids. A slightly higher mortality (although not significant) in cadmium-exposed, uninfected Gammarus fossarum compared to $P$. minutus-infected individuals was also found by Chen et al. [63]. The mechanisms by which an acanthocephalan infection in gammarids can potentially be beneficial remain largely unclear. Independently of gender, unexposed infected G. roeseli had lower protein and lipid contents but higher levels of glycogen [59]. Increased glycogen levels in acanthocephalaninfected gammarids seems to be a common phenomenon [63] and might result from an increased uptake of nutrients due to extended energy requirements [88]. Under polluted conditions the need for detoxification of pollutants can cause increased metabolic activity. Gismondi et al. [62] described an increase of several host antitoxic defence capacities in $P$. minutus-infected $G$. roeseli females following cadmium toxicity although infection increases cadmium toxicity in G. roeseli females.

Examples showing additive negative effects of parasites and pollutants are more frequently found than beneficial effects. For example, Gheorgiu et al. [89] demonstrated a strong increase in mortality if guppies (Poecilia reticulata) were simultaneously exposed to $\mathrm{Zn}$ and infected with the monogenean Gyrodactylus turnbulli. Also for 
other fish species as well as amphibians many examples exist which show that pathogenicity of parasites may be enhanced under polluted conditions, many of which represent a field-based approach [53, 64, 82, 90-93]. In summary, most papers suggest a worsening of pollutioninduced adverse effects by parasites. However, it cannot be excluded that parasite-reduced pollutant concentrations in infected hosts might be beneficial when hosts face environmental pollution, as lower pollutant levels are usually associated with less toxic effects. This assumption has to be studied in more detail in future investigations with a clear focus on the question if negative effects of a parasitosis may be outweighed by a potentially positive impact of reduced pollutant levels. When tackling these aspects, further consequences on the population and ecosystem levels should be addressed.

\section{Contaminant effects on free-living stages of parasites}

In addition to a possible use of parasites as accumulation indicators several studies also focus on effect indication with parasites on the level of individual organisms, populations and communities. Effect indication on the individual level might be possible using the direct toxicity of substances on free-living parasitic stages, mainly those of digeneans such as miracidia and cercariae (reviewed in [94]). Within these studies a known number of larval stages were treated with chemicals, mainly metals, and the subsequent longevity, viability and infectivity of the stages were analysed $[55,94]$. This research was done with two goals in mind: first, to determine if studies of effects of pollution on free-living stages could help evaluate changes in parasite populations in polluted waters, and second, to develop the use of free-living stages of parasites, in particular, the asexually-produced cercariae emerging from infected molluscan hosts, as sensitive toxicity indicators. However, little work has been aimed at evaluating the effects of pollution on infectivity of free-living stages of parasites [94]. Since that time, there has not been much advancement in this area of research. Most of the activity focused on agricultural systems and the effects of pesticides and eutrophication, with varying results. For example, atrazine has been shown to have negative effects on echinostome cercariae, impeding transmission and decreasing infection levels, but also negative effects on anuran tadpole hosts, increasing susceptibility and infection levels [95]. Various pesticides were shown to cause mortality of echinostome cercariae, yet sublethal exposures did not reduce infectivity [96]. These authors also found that pesticide exposure increased susceptibility of tadpoles to infection to a greater degree than it impeded cercarial transmission, resulting in net increases in infection [96]. In another study, cercarial mortality was increased and survival decreased to varying degrees in two trematodes exposed to different concentrations of atrazine [97]. Cercariae of another echinostome suffered reduced survival following exposure to each of six different insecticides, but not in a dose-dependent manner [98]. This calls into question the potential use of toxicity assays in predicting pesticide toxicity to parasites [98]. In contrast to these studies, echinostome eggs and miracidia were not affected by exposure to any of four pesticides [99]. In a fish study, infectivity of two diplostomatid cercariae was reduced following exposure to cadmium, even at low doses for short time periods [100].

Aside from trematodes, and also infecting anurans, another parasite attracting attention is the chytrid fungus, responsible for numerous amphibian declines and extinctions worldwide [101]. Three different pesticides tested inhibited zoospore production, while two of three inhibited zoosporangia development, and all three caused mortality of both fungal stages [102].

Parasite responses to eutrophication, another byproduct of agricultural activity, were very different from those to pesticides and other contaminants by comparison. Infections of Ribeiroia ondatrae, a trematode responsible for frog malformations, increased following eutrophication (see also section on Ecosystem health). Not only did eutrophication lead to an increased density of infected snails, but it resulted in an increase in the per-capita cercarial production by infected snails [103].

With respect to a possible use of free-living stages as sensitive toxicity indicators several studies showed a reduced infectivity and longevity of cercariae. Following the first reports on the sensitivity of cercariae to metal ions published by Evans [104, 105] a possible application of metal ions was tested as a treatment against cercariae of disease-causing Schistosoma sp. (e.g. [106-109]). In the meantime, miracidia and cercariae of many other trematode species were tested for their sensitivity to metal pollution in laboratory exposure studies [55, 94]. However, compared with conventional effect indication procedures, such as the automatic mussel monitor [110], cercarial test systems appear to be less applicable as toxicity indicators. Moreover, due to the relatively short life span of cercariae, a monitoring system using these organisms would be too complicated to be routinely used.

\section{Parasites as indicators of ecosystem health}

Undoubtedly, parasites are important and integral elements in aquatic ecosystems in which they drive fundamental ecological processes, e.g. by contributing to a system's biodiversity, productivity and food web structure or ecosystem engineering (e.g. [111, 112]). A healthy, i.e. functioning and resilient [113], ecosystem is therefore a system rich in parasite species [13, 114]. As 
with free-living species, parasites respond to ecosystem disturbances and can provide valuable information about a system's quality, integrity and health in response to pollutants and other stressors. Other than the use of parasites as accumulation indicators, e.g. when assessing the biological availability of pollutants, environmental impacts are usually assessed via changes in an organism's behaviour or numbers, which acts as an effect indicator [94]. However, just like free-living taxa, different parasite taxonomic groups react differently to environmental impacts (see meta-analyses by Lafferty [10]; Blanar et al. [14]; Vidal-Martínez et al. [15]). It is therefore important that suitable parasite taxa are chosen as bioindicators in accordance with the research question, and that different parasite taxonomic groups are not randomly pooled when analysing environmental stressors [13, 15]. However, grouping parasites into different functional groups has been shown to provide useful results and insights, e.g. when comparing monoxenous (single host lifecycle) and heteroxenous (multi-host life-cycle) parasites, endo- and ectoparasites, allogenic and autogenic parasites, planktonic $v s$ benthic life-cycles, or species sharing common life-cycle pathways $[13,14]$.

Ectoparasites and free-living parasite dispersal stages (e.g. cercariae, coracidia) show clear parallels to freeliving animals, since they are in direct contact with their environment and toxic substances can directly affect them, reducing their vitality or increasing mortality (see above $[94,115])$, and thus leading to changes in composition and diversity of parasite communities. For example, the occurrence of monogenean ectoparasites on fish as well as the hatchability and survival of their larvae was found to be negatively affected by high metal concentration in water [116-118]. Exposure to $\mathrm{Zn}$ also reduced reproduction and survival of Gyrodactylus turnbulli on guppies [119]. Curiously, maximum intensities of $G$. turnbulli on guppies were observed at low to moderate concentrations, but declined at higher levels of $\mathrm{Zn}$ [89]. These results highlight the differential impact of contaminants on parasites and their hosts, affecting the dynamics of the host-parasite relationship. Endoparasites on the other hand live within their host and environmental effects usually manifest first at the level of the host and subsequently can be detected at the parasite level. Altogether, environmental pollution was shown to have generally stronger, mostly negative, effects on directly exposed parasites (i.e. free-living stages and ectoparasites) when compared with endoparasites [14].

In contrast to monoxenous parasites, heteroxenous parasites require one or more hosts for their transmission and their distribution is dependent on the presence of all hosts in their life-cycle [13, 112, 120]. Higher pollutant exposure concentration and duration might perturb the life functions of the host (intermediate, paratenic or final), leading to lower reproduction rates and/or higher mortality, which should reduce host population size. Under certain conditions, hosts of other parasites may proliferate, leading to increases in the transmission of their parasites, as can be observed with eutrophication [13]. As mentioned above, pollutants also can directly affect free-living stages of parasites, reducing their populations [94]. Given that the different groups of parasites have life-cycles that use various components of the food web for transmission, changes in composition and diversity of heteroxenous parasite communities can provide information about the environmental impact on the food web that led to the disruption or enhancement of the transmission of the various parasites in that community $[13,112]$. Because of this direct linkage of heteroxenous parasites to the free-living host communities at different trophic levels, these organisms are considered sensitive bioindicators for aquatic ecosystem health $[13,112]$.

However, as stated above, meta-analytical approaches have shown that monoxeneous taxa tend to show a higher susceptibility to a larger variety of environmental stressors [14]. Does this mean that monoxeneous endoparasite taxa are the most sensitive and reliable bioindicators? This would certainly be an overgeneralization, given the specific and sometimes contradicting responses even within functional groups. The following recent studies therefore provide some examples of promising parasitic bioindicators that do not fit to this general pattern.

Digenean trematodes offer promising effect indicators due to their complex life-cycles with a first intermediate molluscan host and a wide variety of definitive hosts (e.g. birds, mammals, amphibians), as well as second intermediate hosts, such as fish, molluscs, insects or crustaceans that are all necessary to complete and maintain the life-cycle. Field investigations have shown that the prevalence of digeneans in their intermediate and definitive hosts are inversely related to the degree of pollution and disturbance of aquatic ecosystems ([121] and references therein), and trematode diversity indices might work as well as established insect diversity indices to assess ecosystem health [122, 123]. Furthermore, due to their complex multi-host life-cycles, trematodes are reliable indicators of free-living species diversity [124] and can reveal the trophic interactions within an ecosystem.

Also the composition and diversity of total parasite communities of a particular host (e.g. fish) were found to reflect the ecological condition of habitats where the host occurs. For example, Nachev \& Sures [125] and Chapman et al. [126] reported higher parasite diversity at less polluted sampling sites, whereas the composition of the parasite fauna and the abundance of some 
parasites showed a clear relationship with the pollution gradient. Furthermore, various studies demonstrate, for example, that toxic pollution reduces the diversity of heteroxenous parasites, whereas parasites with direct life-cycles (monoxenous) are less affected (e.g. [127]), despite the results of the meta-analyses described above. The proliferation of certain monoxenous parasites likely is due to an impaired host immune response in polluted conditions [13, 112]. Given that monoxenous parasites show a different susceptibility to pollution than heteroxenous ones, the ratio between species richness of heteroxenous and monoxenous $\left(\mathrm{S}_{\mathrm{H}} / \mathrm{S}_{\mathrm{M}}\right)$ parasites can be used as a measure of pollution impact, showing distinctively higher $\mathrm{S}_{\mathrm{H}} / \mathrm{S}_{\mathrm{M}}$ ratios on/in fish in unpolluted marine habitats in comparison to fish sampled from polluted habitats ([127] and references therein). While species composition and richness did not change along a pollution gradient in a northern Canadian river, the relative abundance of a monoxenous monogenean ectoparasite increased and then decreased, while that of a heteroxenous larval trematode decreased then increased as the river coursed through a heavily-impacted mining area [128].

In using parasites as indicators of ecosystem stress and environmental degradation, it is important to disentangle effects caused by contaminants from those caused by other abiotic or biotic factors. For example, in a study examining effects of municipal effluents in a large North American river, fish parasite communities were affected primarily by water mass, year and season [129]. This study highlights the importance of good sample design and replication. This point is supported by other studies which showed large-scale hydrological effects on parasite communities to be more pronounced than those of contaminants [130-132]. Indeed, Marcogliese et al. ([129] and references therein) suggested that parasite communities as indicators may not be sensitive enough to detect effects of low to moderate pollution or that effects may be overshadowed by those of natural environmental variation. This reinforces the point above that circumstances will dictate the choice of parasite indicator, be it a particular taxon, guild or functional group [13]. This is nicely illustrated by another study in the same river and on the same fish species as in [129], replicated over 5 years, that showed the species richness and prevalence of myxozoan parasites in the same fish increased downstream of a large municipal effluent [130]. The study further demonstrated that the effects were due to eutrophication leading to the proliferation of oligochaete alternate hosts and not contaminant toxicity.

Another important development of the last decade where there has been a wealth of research has been the examination of the effects of pesticides on anuran parasites in North America and their interaction, largely spurred forward by the controversy over the herbicide atrazine, which is banned in Europe [133, 134], as well as the marked increase in reports of malformations in frogs [135]. These studies have examined the effects of pesticides experimentally in mesocosms as well as in the field, focusing on either selected parasite species, trematodes as a whole, or entire communities [103, 136-143]. Two general patterns have emerged from these studies. First, there is renewed interest in eutrophication and disease [144-146]. Secondly, parasite communities appear to reflect the landscape structure of their hosts' habitat. A variety of studies examining the effects of pesticides on frog parasite communities have independently found that abundance of trematodes or parasite species richness are positively correlated with the surrounding forest area, and negatively correlated with the amount of urban or agricultural area [137-143]. Landscape also was associated with changes in community structure in fishes in streams and rivers [128, 147]. Another significant step forward from these initiatives is the application of an experimental mesocosm approach to examine the effects of pesticides on host-parasite interactions within simulated communities, allowing the disentanglement of direct toxic effects and indirect ecological effects along with the mechanisms involved [103, 141]. Furthermore, manipulation of parasite life-cycles within the laboratory also has permitted the determination of the mechanisms involved in direct and indirect effects of pesticides on host-parasite interactions [96].

Apart from measuring and indicating anthropogenic ecosystem disturbances, such as pollution and degradation, parasites can help to monitor and assess the redevelopment and restoration of ecological habitats that were converted into more 'productive' or useful systems in the past. These changes and alterations of landscapes and aquatic systems have resulted in extensive degradation of ecosystems and the loss of biodiversity on a global scale [148]. The last decades have seen the implementation of rehabilitation and restoration schemes to reverse such degradation and recreate the original/natural (or near-natural) state of ecosystems. Measuring the success and impacts on a restored ecosystem and its biodiversity is crucial to assess such actions and benthic macroinvertebrates and fishes are commonly used as bioindicators [148]. Additionally, heteroxenous parasites with complex life-cycles, such as trematodes, have proven to be suitable assessment tools for the restoration of waterways and wetlands and have been shown to reflect the level of restoration success (e.g. [13, 123, 149]). However, despite their promising application, only few studies have applied snail-trematode systems to assess the effect of aquatic restoration projects to date and more studies should address this potentially very interesting field of research in the future to obtain a more complete picture 
of the free-living and parasite diversity and community structure in these systems.

While the number of studies using or including parasites as indicators to assess ecosystem health is slowly but steadily increasing, we certainly need more studies to unravel and better understand the different and sometimes opposing effects of environmental impacts on different parasite taxa. Also, as Vidal-Matínez et al. [15] point out, it is important to establish the threshold at which certain parasite groups respond to environmental impacts. Selected parasite groups show the high potential as indicators of ecological health, when chosen according to the research question and when studies are carefully designed; e.g. trematode communities in aquatic habitat restoration assessments [123, 149], or the use of heteroxenous and monoxenous parasite ratios as indicators of pollution impact [127]. As Blanar et al. [14] conclude, the final choice of indicator taxa should be based on local ecology, parasite biology, and the specific research question that is to be addressed.

Lastly, resource managers and scientists should not rely on a single pollution indicator. The use of parasites as indicators should be combined with other indicators to obtain the most comprehensive understanding of the pollution problem in question [13, 150, 151]. For example, Vidal-Martínez et al. [152] examined contaminant levels and parasites within the same individual shrimp hosts. Another study utilized chemical measurements of the sediments, plus physiological biomarkers and parasites from the same individual fish [153]. Most recently, a study in a large river measured metals in surface waters, along with stable isotopes, condition, histological examination, transcriptomic and biochemical analyses and selected parasites in the same fish [154, 155]. Marcogliese et al. [156] summarizes a multidisciplinary research program, including parasitology, aimed at examining the effects of a major municipal effluent on the same large river ecosystem.

\section{Conclusions}

The research directions reviewed here show that parasites can be considered as organisms whose responsiveness might be advantageous to the understanding of environmental problems. Apart from highlighting promising research directions and identifying future research needs, the current paper should make non-parasitologists aware of parasites by exemplifying the sensitivity of these organisms to environmental changes as well as by focusing on the physiological effects parasites may have on their hosts. The selected examples and ideas on the other hand may enable parasitologists to consider and treat parasites not only as creatures that threaten the health of their hosts but also as responsive organisms with applied bioindication value in an environmental sense.
Availability of data and materials

All data were provided in the manuscript.

Authors' contributions

All authors were involved in writing process, read and approved the final manuscript.

\section{Competing interests}

The authors declare that they have no competing interests.

\section{Consent for publication}

Not applicable.

\section{Ethics approval and consent to participate}

Not applicable.

\section{Author details}

${ }^{1}$ Aquatic Ecology and Centre for Water and Environmental Research, University of Duisburg-Essen, Universitätsstr. 5, D-45141 Essen, Germany. ${ }^{2}$ Department of Zoology, University of Johannesburg, PO Box 524, Auckland Park 2006, Johannesburg, South Africa. ${ }^{3}$ Water Research Group, Unit for Environmental Sciences and Management, North-West University, Private Bag X6001, Potchefstroom 2520, South Africa. ${ }^{4}$ Aquatic Contaminants Research Division, Water Science and Technology Directorate, Science and Technology Branch, Environment and Climate Change Canada, St. Lawrence Centre, 105 McGill Street, 7th floor, Montreal, QC H2Y 2E7, Canada. ${ }^{5}$ St. Andrews

Biological Station, Fisheries and Oceans Canada, 531 Brandy Cove Road, St, Andrews, NB E5B 2 L9, Canada.

Received: 5 November 2016 Accepted: 24 January 2017

Published online: 06 February 2017

\section{References}

1. Goater TM, Goater CP, Esch GW. Parasitism: the diversity and ecology of animal parasites. Cambridge: Cambridge University Press; 2013.

2. Sures B, Nachev M. Environmental Parasitology. Encyclopedia of parasitology. 2015. p. 1-4.

3. Snieszko SF. The effects of environmental stress on outbreaks of infectious diseases of fishes. J Fish Biol. 1974;6:197-208.

4. Sindermann CJ. The use of pathological effects of pollutants in marine environmental monitoring programs. Rapp P-v Réun Cons Int Explor Mer. 1980;179:129-34.

5. Möller H. Pollution and parasitism in the aquatic environment. Int J Parasitol. 1987;17:353-61.

6. Khan RA, Thulin J. Influence of pollution on parasites of aquatic animals. Adv Parasitol. 1991;30:201-38.

7. Poulin R. Toxic pollution and parasitism in freshwater fish. Parasitol Today. 1992;8:58-61.

8. Overstreet RM. Parasitic diseases of fishes and their relationship with toxicants and other environmental factors. In: Raton B, editor. Pathobiology of marine and estuarine organisms. Boca Raton: CRC press; 1993. p. 111-56.

9. MacKenzie K, Williams HH, Williams B, McVicar AH, Siddall R. Parasites as indicators of water quality and the potential use of helminth transmission in marine pollution studies. Adv Parasitol. 1995;35:128-44.

10. Lafferty KD. Environmental Parasitology: what can parasites tell us about human impacts on the environment? Parasitol Today. 1997;13:251-5.

11. Sures $B$, Siddall $R$, Taraschewski $H$. Parasites as accumulation indicators of heavy metal pollution. Parasitol Today. 1999;15:16-21.

12. Sures B. Environmental Parasitology: relevancy of parasites in monitoring environmental pollution. Trends Parasitol. 2004;20:170-7.

13. Marcogliese DJ. Parasites of the superorganism: Are they indicators of ecosystem health? Int J Parasitol. 2005;35:705-16.

14. Blanar CA, Munkittrick KR, Houlahan J, MacLatchy DL, Marcogliese DJ. Pollution and parasitism in aquatic animals: a meta-analysis of effect size. Aquat Toxicol. 2009;93:18-28.

15. Vidal-Martínez VM, Pech D, Sures B, Purucker ST, Poulin R. Can parasites really reveal environmental impact? Trends Parasitol. 2010;26:44-51.

16. Sures B. Accumulation of heavy metals by intestinal helminths in fish: an overview and perspective. Parasitology. 2003;126:53-60.

17. Sures B. Environmental parasitology. Interactions between parasites and pollutants in the aquatic environment. Parasite. 2008;15:434-8. 
18. Sures B. Host-parasite interactions in polluted environments. J Fish Biol. 2008;73:2133-42.

19. Nachev M, Sures B. Environmental Parasitology: parasites as accumulation bioindicators in the marine environment. J Sea Res. 2016;113:45-50.

20. Le Yen TT, Rijsdijk L, Sures B, Jan HA. Accumulation of persistent organic pollutants in parasites. Chemosphere. 2014;108:145-51.

21. Sures B, Siddall R. Pomphorhynchus laevis: the intestinal acanthocephalan as a lead sink for its fish host, chub (Leuciscus cephalus). Exp Parasitol. 1999;93: 66-72.

22. Amiard-Triquet C, Amiard JC, Mouneyrac C. Aquatic ecotoxicology. London: Academic; 2015

23. Sures $B$, Taraschewski $H$, Jackwerth E. Lead accumulation in Pomphorhynchus laevis and its host. J Parasitol. 1994;80:355-7.

24. Sures B, Taraschewski H. Cadmium concentrations in two adult acanthocephalans, Pomphorhynchus laevis and Acanthocephalus lucii, as compared with their fish hosts and cadmium and lead levels in larvae of $A$. lucii as compared with their crustacean host. Parasitol Res. 1995;81:494-7.

25. Malek M, Haseli M, Mobedi I, Ganjali MR, MacKenzie K. Parasites as heavy metal bioindicators in the shark Carcharhinus dussumieri from the Persian Gulf. Parasitology. 2007;134:1053-6.

26. Oluoch-Otiego J, Oyoo-Okoth E, Kiptoo KKG, Chemoiwa EJ, Ngugi CC, Simiyu G, et al. PCBs in fish and their cestode parasites in Lake Victoria. Environ Monit Assess. 2016;188:483.

27. Nachev M, Schertzinger G, Sures B. Comparison of the metal accumulation capacity between the acanthocephalan Pomphorhynchus laevis and larval nematodes of the genus Eustrongylides sp. infecting barbel (Barbus barbus). Parasit Vectors. 2013;6:21.

28. Amini Z, Pazooki J, Abtahi B, Shokri MR. Bioaccumulation of $\mathrm{Zn}$ and $\mathrm{Cu}$ in Chasar bathybius (Gobiidae) tissue and its nematode parasite Dichelyne minutus, southeast of the Caspian Sea. Iran Indian J Mar Sci. 2013;42:196-200.

29. Starling JA. Feeding, nutrition and metabolism. In: Crompton DWT, Nickol BB, editors. Biology of the Acanthocephala. Cambridge: Cambridge University Press; 1985. p. 125-212

30. Tellez M, Merchant M. Biomonitoring heavy metal pollution using an aquatic apex predator, the American alligator, and its parasites. PLoS One. 2015;10, e0142522

31. Lotfy WM, Ezz AM, Hassan AAM. Bioaccumulation of some heavy metals in the liver flukes Fasciola hepatica and F. gigantica. Iran J Parasitol. 2013;8:552-8.

32. Sures $B$, Jürges $G$, Taraschewski H. Relative concentrations of heavy metels in the parasites Ascaris suum (Nematoda) and Fasciola hepatica (Digenea) and their respective porcine and bovine definitive hosts. Int J Parasitol. 1998:28:1173-8.

33. Chang ACG, Flores MJC. Morphology and viability of adult Fasciola gigantica (giant liver flukes) from Philippine carabaos (Bubalus bubalis) upon in vitro exposure to lead. Asian Pac J Trop Biomed. 2015;5:493-6.

34. Qian G, Pin N. Lead content in the monogenean, Ancyrocephalus mogurndae and in different organs of its host, the mandarin fish, Siniperca chuatsi. China Env Sci. 2000;20:233-6.

35. Torres J, Eira C, Miquel J, Foronda P, Feliu C. Cadmium and lead concentrations in Moniliformis moniliformis (Acanthocephala) and Rodentolepis microstoma (Cestoda), and in their definitive hosts, Rattus rattus and Mus domesticus in El Hierro (Canary Archipelago, Spain). Acta Parasitol. 2011;56:320-4

36. Sures B, Franken M, Taraschewski H. Element concentrations in the archiacanthocephalan Macracanthorhynchus hirudinaceus compared with those in the porcine definitive host from a slaughterhouse in La Paz, Bolivia. Int J Parasitol. 2000;30:1071-6.

37. Sures $B$, Jürges $G$, Taraschewski H. Accumulation and distribution of lead in the archiacanthocephalan Moniliformis moniliformis from experimentally infected rats. Parasitology. 2000;121:427-33.

38. Sures B, Reimann N. Analysis of trace metals in the Antarctic host-parasite system Notothenia coriiceps and Aspersentis megarhynchus (Acanthocephala) caught at King George Island, South Shetland Islands. Polar Biol. 2003;26: 680-6.

39. Cobelo-García A, Filella M, Croot P, Frazzoli C, Du Laing G, Ospina-Alvarez N, et al. COST action TD1407: network on technology-critical elements (NOTICE) - from environmental processes to human health threats. Environ Sci Pollut Res. 2015;22:15188-94.

40. Sures B, Thielen F, Baska F, Messerschmidt J, Von Bohlen A. The intestinal parasite Pomphorhynchus laevis as a sensitive accumulation indicator for the platinum group metals Pt, Pd, and Rh. Environ Res. 2005;98:83-8.
41. Zimmermann S, Von Bohlen A, Messerschmidt J, Sures B. Accumulation of the precious metals platinum, palladium and rhodium from automobile catalytic converters in Paratenuisentis ambiguus as compared with its fish host, Anquilla anquilla. J Helminthol. 2005;79:85-9.

42. Zimmermann S, Messerschmidt J, Von Bohlen A, Sures B. Uptake and bioaccumulation of platinum group metals ( $\mathrm{Pd}, \mathrm{Pt}, \mathrm{Rh})$ from automobile catalytic converter materials by the zebra mussel (Dreissena polymorpha). Environ Res. 2005;98:203-9.

43. Gabrashanska M, Nedeva I. Content of heavy metals in the system fishcestodes. Parassitologia. 1996;38:58.

44. Turcekova L, Hanzelova V. Concentrations of $\mathrm{Cd}$, As and Pb in non-infected and infected Perca fluviatilis with Proteocephalus percae. Helmintologia. 1999;36:31.

45. Sures B, Dezfuli BS, Krug HF. The intestinal parasite Pomphorhynchus laevis (Acanthocephala) interferes with the uptake and accumulation of lead (210Pb) in its fish host chub (Leuciscus cephalus). Int J Parasitol. 2003;33:1617-22.

46. Oyoo-Okoth E, Wim A, Osano O, Kraak MH, Ngure V, Makwali J, et al. Use of the fish endoparasite Ligula intestinalis (L., 1758) in an intermediate cyprinid host (Rastreneobola argentea) for biomonitoring heavy metal contamination in Lake Victoria, Kenya. Lakes Reserv Res Manag. 2010;15:63-73.

47. Le YTT, Nachev M, Grabner D, Hendriks AJ, Sures B. Development and validation of a biodynamic model for mechanistically predicting metal accumulation in fish-parasite systems. PLoS One. 2016;11, e0161091.

48. Livingstone DR, Förlin L, George SG. Molecular biomarkers and toxic consequences of impact by organic pollution in aquatic organisms. In: Suthcliffe DW, editor. Water quality and stress indicators in marine and freshwater systems: Linking levels of organization. Ambleside: Freshwater Biological Association; 1994. p. 154-71.

49. Forbes VE, Palmqvist A, Bach L. The use and misuse of biomarkers in ecotoxicology. Environ Toxicol Chem. 2006;25:272-80.

50. Binelli A, Della Torre C, Magni S, Parolini M. Does zebra mussel (Dreissena polymorpha) represent the freshwater counterpart of Mytilus in ecotoxicological studies? A critical review. Env Pollut. 2015;196:386-403.

51. Amoozadeh E, Malek M, Rashidinejad R, Nabavi SM, Karbassi MR, Ghayoumi $R$, et al. Marine organisms as heavy metal bioindicators in the Persian Gulf and the Gulf of Oman. Environ Sci Pollut R. 2014;21:2386-95.

52. Huang GY, Liu YS, Liang YQ, Shi WJ, Hu LX, Tian F, et al. Multi-biomarker responses as indication of contaminant effects in Gambusia affinis from impacted rivers by municipal effluents. Sci Total Env. 2016;563:273-81.

53. Marcogliese DJ, Pietrock M. Combined effects of parasites and contaminants on animal health: parasites do matter. Trends Parasitol. 2011;27:123-30.

54. Le TTY, Zimmermann S, Sures B. How does the metallothionein induction in bivalves meet the criteria for biomarkers of metal exposure? Environ Pollut. 2016;212:257-68.

55. Morley NJ, Lewis JW, Hoole D. Pollutant-induced effects on immunological and physiological interactions in aquatic host-trematode systems: implications for parasite transmission. J Helminthol. 2006;80:137-49.

56. Sures B. How parasitism and pollution affect the physiological homeostasis of aquatic hosts. J Helminthol. 2006;80:151-7.

57. Morley NJ. Interactive effects of infectious diseases and pollution in aquatic molluscs. Aquat Toxicol. 2010;96:27-36.

58. Sures B, Radszuweit H. Pollution induced heat shock protein expression in the amphipod Gammarus roeseli is affected by larvae of Polymorphus minutus (Acanthocephala). J Helminthol. 2007:81:191-7.

59. Gismondi E, Beisel J-N, Cossu-Leguille C. Polymorphus minutus affects antitoxic responses of Gammarus roeseli exposed to cadmium. PLoS One. 2012;7, e41475.

60. Ewald PW. The evolution of virulence: a unifying link between Parasitology and ecology. J Parasitol. 1995;81:659-69.

61. Martínez-Alvarez RM, Morales AE, Sanz A. Antioxidant defenses in fish: biotic and abiotic factors. Rev Fish Biol Fish. 2005;15:75-88.

62. Gismondi E, Cossu-Leguille C, Beisel J-N. Does the acanthocephalan parasite Polymorphus minutus modify the energy reserves and antitoxic defences of its intermediate host Gammarus roeseli? Parasitology. 2012; 139:1054-61.

63. Chen HY, Grabner DS, Nachev M, Shih SH, Sures B. Effect of the acanthocephalan Polymorphus minutus and the microsporidian Dictyocoela duebenum on energy reserves and stress response of cadmium exposed Gammarus fossarum. PeerJ. 2015;3:e1353.

64. Frank SN, Godehardt S, Nachev M, Trubiroha A, Kloas W, Sures B. Influence of the cestode Ligula intestinalis and the acanthocephalan Polymorphus minutus on levels of heat shock proteins (HSP70) and metallothioneins in their fish and crustacean intermediate hosts. Env Pollut. 2013;180:173-9. 
65. Baudrimont M, de Montaudouin X, Palvadeau A. Impact of digenean parasite infection on metallothionein synthesis by the cockle (Cerastoderma edule): a multivariate field monitoring. Mar Pollut Bull. 2006;52:494-502.

66. Baudrimont $\mathrm{M}$, de Montaudouin X. Evidence of an altered protective effect of metallothioneins after cadmium exposure in the digenean parasiteinfected cockle (Cerastoderma edule). Parasitology. 2007;134:237-45.

67. Kloas W, Urbatzka R, Opitz R, Würtz S, Behrends T, Hermelink B, et al. Endocrine disruption in aquatic vertebrates. Ann NY Acad Sci. 2009;1163:187-200.

68. Segner H. Developmental, reproductive, and demographic alterations in aquatic wildlife: establishing causality between exposure to endocrine-active compounds (EACs) and effects. Acta Hydrochim Hydrobiol. 2005;33:17-26.

69. Rodgers-Gray TP, Smith JE, Ashcroft AE, Isaac RE, Dunn AM. Mechanisms of parasite-induced sex reversal in Gammarus duebeni. Int J Parasitol. 2004;34:747-53.

70. Terry RS, Smith JE, Sharpe RG, Rigaud T, Littlewood DTJ, Ironside JE, et al. Widespread vertical transmission and associated host sex-ratio distortion within the eukaryotic phylum Microspora. Proc R Soc B Biol Sci. 2004;271:1783-9.

71. Hecker M, Karbe L. Parasitism in fish - An endocrine modulator of ecological relevance? Aquat Toxicol. 2005;72:195-207.

72. Morley NJ. Parasitism as a source of potential distortion in studies on endocrine disrupting chemicals in molluscs. Mar Pollut Bull. 2006;52:1330-2.

73. Morley NJ. Environmental risk and toxicology of human and veterinary waste pharmaceutical exposure to wild aquatic host-parasite relationships. Environ Toxicol Pharmacol. 2009;27:161-75.

74. Arme C, Owen RW. Occurrence and pathology of Ligula intestinalis infections in British fishes. J Parasitol. 1968;54:272-80.

75. Arme C. Ligula intestinalis: Interactions with the pituitary-gonadal axis of its fish host. J Helminthol. 1997;71:83-4.

76. Carter V, Pierce R, Dufour S, Arme C, Hoole D. The tapeworm Ligula intestinalis (Cestoda: Pseudophyllidea) inhibits LH expression and puberty in its teleost host, Rutilus rutilus. Reproduction. 2005;130:939-45.

77. Trubiroha A, Wuertz S, Frank SN, Sures B, Kloas W. Expression of gonadotropin subunits in roach (Rutilus rutilus, Cyprinidae) infected with plerocercoids of the tapeworm Ligula intestinalis (Cestoda). Int J Parasitol. 2009:39:1465-73.

78. Trubiroha A, Kroupova H, Wuertz S, Frank SN, Sures B, Kloas W. Naturallyinduced endocrine disruption by the parasite Ligula intestinalis (Cestoda) in roach (Rutilus rutilus). Gen Comp Endocrinol. 2010;166:234-40.

79. Trubiroha A, Kroupova H, Frank SN, Sures B, Kloas W. Inhibition of gametogenesis by the cestode Ligula intestinalis in roach (Rutilus rutilus) is attenuated under laboratory conditions. Parasitology. 2011;138:648-59.

80. Sanchez-Ramirez C, Vidal-Martínez VM, Aguirre-Macedo ML, Rodriguez-Canul RP, Gold-Bouchot G, Sures B. Cichlidogyrus sclerosus (Monogenea: Ancyrocephalinae) and its host, the Nile tilapia (Oreochromis niloticus), as bioindicators of chemical pollution. J Parasitol. 2007;93:1097-106.

81. Bichet C, Scheifler R, Cœurdassier M, Julliard R, Sorci G, Loiseau C. Urbanization, trace metal pollution, and malaria prevalence in the house sparrow. PLoS One. 2013;8, e53866.

82. Marcogliese DJ, Dautremepuits C, Gendron AD, Fournier M. Interactions between parasites and pollutants in yellow perch (Perca flavescens) in the St. Lawrence River, Canada: Implications for resistance and tolerance to parasites. Can J Zool. 2010;88:247-58.

83. Sánchez MI, Pons I, Martínez-Haro M, Taggart MA, Lenormand T, Green AJ. When parasites are good for health: Cestode parasitism increases resistance to arsenic in brine shrimps. PLoS Pathog. 2016;12:1-19.

84. Heinonen J, Kukkonen JVK, Holopainen IJ. Temperature and parasiteinduced changes in toxicity and lethal body burdens of pentachlorophenol in the freshwater clam Pisidium amnicum. Env Toxicol Chem. 2001;20:2778-84.

85. McCahon CP, Brown AF, Pascoe D. The effect of the acanthocephalan Pomphorhynchus laevis (Muller 1776) on the acute toxicity of cadmium to its intermediate host, the amphipod Gammarus pulex (L.). Arch Environ Contam Toxicol. 1988;17:239-43.

86. Brown AF, Pascoe D. Parasitism and host sensitivity to cadmium: an acanthocephalan infection of the freshwater amphipod Gammarus pulex. J Appl Ecol. 1989;26:473-87.

87. Gismondi E, Cossu-Leguille C, Beisel JN. Acanthocephalan parasites: help or burden in gammarid amphipods exposed to cadmium? Ecotoxicology. 2012:21:1188-93.

88. Sparkes TC, Keogh DP, Pary RA. Energetic costs of mate guarding behavior in male stream-dwelling isopods. Oecologia. 1996;106:166-71.

89. Gheorgiu C, Marcogliese DJ, Scott M. Concentration-dependent effects of waterborne zinc on population dynamics of Gyrodactylus turnbulli (Monogenea) on isolated guppies (Poecilia reticulata). Parasitology. 2006;132:225-32.
90. Marcogliese DJ, Brambilla LG, Gagné F, Gendron AD. Joint effects of parasitism and pollution on oxidative stress biomarkers in yellow perch Perca flavescens. Dis Aquat Organ. 2005;63:77-84.

91. Thilakaratne IDSIP, McLaughlin JD, Marcogliese DJ. Effects of pollution and parasites on biomarkers of fish health in spottail shiners Notropis hudsonius (Clinton). J Fish Biol. 2007;71:519-38.

92. Marcogliese DJ, King KC, Salo HM, Fournier M, Brousseau P, Spear P, et al. Combined effects of agricultural activity and parasites on biomarkers in the bullfrog, Rana catesbeiana. Aquat Toxicol. 2009;91:126-34.

93. Koprivnikar J. Interactions of environmental stressors impact survival and development of parasitized larval amphibians. Ecol Appl. 2010;20:2263-72.

94. Pietrock M, Marcogliese DJ. Free-living endohelminth stages: at the mercy of environmental conditions. Trends Parasitol. 2003:19:293-9.

95. Koprivnikar J, Forbes MR, Baker RL. Contaminant effects on host-parasite interactions: Atrazine, frogs, and trematodes. Environ Toxicol Chem. 2007;26:2166-70.

96. Rohr JR, Raffel TR, Sessions SK, Hudson PJ. Understanding the net effects of pesticides on amphibian trematode infections. Ecol Appl. 2008;18:1743-53.

97. Koprivnikar J, Forbes MR, Baker RL. Effects of atrazine on cercarial longevity, activity, and infectivity. J Parasitol. 2006;92:306-11.

98. Hua J, Buss N, Kim J, Orlofske SA, Hoverman JT. Population-specific toxicity of six insecticides to the trematode Echinoparyphium sp. Parasitology. 2016;143:542-50.

99. Raffel TR, Sheingold JL, Rohr JR. Lack of pesticide toxicity to Echinostoma trivolvis eggs and miracidia. J Parasitol. 2009;95:1548-51.

100. Pietrock M, Goater CP. Infectivity of Ornithodiplostomum ptychocheilus and Posthodiplostomum minimum (Trematoda: Diplostomidae) cercariae following exposure to cadmium. J Parasitol. 2005;91:854-6.

101. Skerratt LF, Berger L, Speare R, Cashins S, McDonald KR, Phillott AD, et al. Spread of chytridiomycosis has caused the rapid global decline and extinction of frogs. Ecohealth. 2007:4:125-34.

102. Hanlon SM, Parris MJ. The impact of pesticides on the pathogen Batrachochytrium dendrobatidis independent of potential hosts. Arch Environ Contam Toxicol. 2012;63:137-43

103. Johnson PTJ, Chase JM, Dosch KL, Hartson RB, Gross JA, Larson DJ, et al. Aquatic eutrophication promotes pathogenic infection in amphibians. Proc Natl Acad Sci USA. 2007:104:15781-6.

104. Evans NA. Effect of copper and zinc upon the survival and infectivity of Echinoparyphium recurvatum cercariae. Parasitology. 1982:85:295-303.

105. Evans NA. Effects of copper and zinc on the life cycle of Notocotylus attenuatus (Digenea: Notocotylidae). Int J Parasitol. 1982;12:363-9.

106. King CL, Higashi Gl. Schistosoma mansoni: Silver ion (Ag+) stimulates and reversibly inhibits lipid-induced cercarial penetration. Exp Parasitol. 1992;75:31-9.

107. Abd Allah AT, Wanas MQ, Thompson SN. The effects of lead, cadmium, and mercury on the mortality and infectivity of Schistosoma mansoni cercariae. J Parasitol. 1996:82:1024-6.

108. Morley NJ, Crane M, Lewis JW. Toxicity of cadmium and zinc to miracidia of Schistosoma mansoni. Parasitology. 2001;122:81-5.

109. Cheng Y, Chen X, Song W, Kong Z, Li P, Liu Y. Contribution of silver ions to the inhibition of infectivity of Schistosoma japonicum cercariae caused by silver nanoparticles. Parasitology. 2013;140:617-25.

110. Borcherding J, Wolf J. The influence of suspended particles on the acute toxicity of 2-chloro-4-nitro-aniline, cadmium, and pentachlorophenol on the valve movement response of the zebra mussel (Dreissena polymorpha). Arch Environ Contam Toxicol. 2001;40:497-504.

111. Poulin R. The functional importance of parasites in animal communities: Many roles at many levels? Int J Parasitol. 1999;29:903-14.

112. Marcogliese DJ. Parasites: Small players with crucial roles in the ecological theater. Ecohealth. 2004;1:151-64.

113. Costanza R, Mageau M. What is a healthy ecosystem? Aquat Ecol. 1999;33:105-15.

114. Hudson PJ, Dobson AP, Lafferty KD. Is a healthy ecosystem one that is rich in parasites? Trends Ecol Evol. 2006;21:381-5.

115. Khalil M, Furness DN, Zholobenko V, Hoole D. Effect of tapeworm parasitisation on cadmium toxicity in the bioindicator copepod, Cyclops strenuus. Ecol Indic. 2014:37:21-6.

116. Gilbert BM, Avenant-Oldewage A. Effects of altered water quality and trace elements on the infection variables of Paradiplozoon ichthyoxanthon (Monogenea: Diplozoidae) from two sites in the Vaal River system, South Africa. Acta Parasitol. 2016:61:52-62.

117. Gilbert BM, Avenant-Oldewage A. Hatchability and survival of oncomiracidia of Paradiplozoon ichthyoxanthon (Monogenea: Diplozoidae) exposed to aqueous aluminium. Parasit Vectors. 2016;9:420. 
118. Blanar CA, MacLatchy DL, Kieffer JD, Munkittrick KR. Exposure to a mixture of zinc and copper decreases survival and fecundity of Discocotyle sagittata (Leuckart) parasitizing juvenile Atlantic salmon, Salmo salar L. Bull Environ Contam Toxicol. 2010;84:692-7.

119. Gheorghiu C, Cable J, Marcogliese DJ, Scott ME. Effects of waterborne zinc on reproduction, survival and morphometrics of Gyrodactylus turnbulli (Monogenea) on guppies (Poecilia reticulata). Int J Parasitol. 2007;37:375-81.

120. Marcogliese DJ. Implications of climate change for parasitism of animals in the aquatic environment. Can J Zool. 2001;79:1331-52.

121. Gérard C, Carpentier A, Paillisson JM. Long-term dynamics and community structure of freshwater gastropods exposed to parasitism and other environmental stressors. Freshw Biol. 2008;53:470-84.

122. Shea J, Kersten GJ, Puccia CM, Stanton AT, Stiso SN, Helgeson ES, et al. The use of parasites as indicators of ecosystem health as compared to insects in freshwater lakes of the Inland Northwest. Ecol Indic. 2012;13:184-8.

123. Huspeni TC, Lafferty KD. Using larval trematodes that parasitize snails to evaluate a saltmarsh restoration project. Ecol Appl. 2004;14:795-804.

124. Hechinger RF, Lafferty KD. Host diversity begets parasite diversity: Bird final hosts and trematodes in snail intermediate hosts. Proc R Soc B Biol Sci. 2005;272:1059-66

125. Nachev M, Sures B. The endohelminth fauna of barbel (Barbus barbus) correlates with water quality of the Danube River in Bulgaria. Parasitology. 2009;136:545-52.

126. Chapman JM, Marcogliese DJ, Suski CD, Cooke SJ. Variation in parasite communities and health indices of juvenile Lepomis gibbosus across a gradient of watershed land-use and habitat quality. Ecol Indic. 2015;57:564-72.

127. Pérez-del Olmo A, Raga JA, Kostadinova A, Fernández M. Parasite communities in Boops boops (L.) (Sparidae) after the Prestige oil-spill: Detectable alterations. Mar Pollut Bull. 2007;54:266-76.

128. Blanar CA, Hewitt M, McMaster M, Kirk J, Wang Z, Norwood W, et al. Parasite community similarity in Athabasca River trout-perch (Percopsis omiscomaycus) varies with local-scale land use and sediment hydrocarbons, but not distance or linear gradients. Parasitol Res. 2016;115:3853-66.

129. Marcogliese DJ, Gendron AD, Plante C, Fournier M, Cyr D. Parasites of spottail shiners (Notropis hudsonius) in the St. Lawrence River: Effects of municipal effluents and habitat. Can J Zool. 2006;84:1461-81.

130. Marcogliese DJ, Gendron AD, Cone DK. Impact of municipal effluents and hydrological regime on myxozoan parasite communities of fish. Int J Parasitol. 2009;39:1345-51

131. Marcogliese DJ, Locke SA, Gélinas M, Gendron AD. Variation in parasite communities in spottail shiners (Notropis hudsonius) linked with precipitation. J Parasitol. 2016;102:27-36.

132. Blanar CA, Marcogliese DJ, Couillard CM. Natural and anthropogenic factors shape metazoan parasite community structure in mummichog (Fundulus heteroclitus) from two estuaries in New Brunswick, Canada. Folia Parasitol. 2011;58:240-8

133. Rohr JR, McCoy KA. A qualitative meta-analysis reveals consistent effects of atrazine on freshwater fish and amphibians. Environ Health Perspect. 2010;118:20-32

134. Rohr JR, Mccoy KA. Preserving environmental health and scientific credibility: A practical guide to reducing conflicts of interest. Conserv Lett. 2010;3:143-50.

135. Blaustein AR, Johnson PTJ. Explaining frog deformities. Sci Am. 2003;288:60-5.

136. Johnson PTJ, Chase JM. Parasites in the food web: Linking amphibian malformations and aquatic eutrophication. Ecol Lett. 2004:7:521-6.

137. Koprivnikar J, Baker RL, Forbes MR. Environmental factors influencing trematode prevalence in grey tree frog (Hyla versicolor) tadpoles in southern Ontario. J Parasitol. 2006;92:997-1001.

138. Koprivnikar J, Baker RL, Forbes MR. Environmental factors influencing community composition of gastropods and their trematode parasites in southern Ontario. J Parasitol. 2007;93:992-8.

139. King KC, McLaughlin JD, Gendron AD, Pauli BD, Giroux I, Rondeau B, et al. Impacts of agriculture on the parasite communities of northern leopard frogs (Rana pipiens) in southern Quebec, Canada. Parasitology. 2007;134: 2063-80.

140. King KC, Daniel Mclaughlin J, Boily M, Marcogliese DJ. Effects of agricultural landscape and pesticides on parasitism in native bullfrogs. Biol Conserv. 2010;143:302-10.

141. Rohr JR, Schotthoefer AM, Raffel TR, Carrick HJ, Halstead N, Hoverman JT, et al. Agrochemicals increase trematode infections in a declining amphibian species. Nature. 2008;455:1235-9.
142. Schotthoefer AM, Rohr JR, Cole RA, Koehler AV, Johnson CM, Johnson LB, et al. Effects of wetland vs. landscape variables on parasite communities of Rana pipiens: Links to anthropogenic factors. Ecol Appl. 2011;21:1257-71.

143. Koprivnikar J, Redfern JC. Agricultural effects on amphibian parasitism: Importance of general habitat perturbations and parasite life cycles. J Wildl Dis. 2012:48:925-36.

144. McKenzie VJ, Townsend AR. Parasitic and infectious disease responses to changing global nutrient cycles. Ecohealth. 2007:4:384-96.

145. Johnson PTJ, Carpenter SR. Influence of eutrophication on disease in aquatic ecosystems: Patterns, processes, and predictions. In: Ostfeld RS, Keesing F, Eviner VT, editors. Infectious disease ecology: effects of ecosystems on disease and of disease on ecosystems. Princeton: Princeton University Press; 2008. p. 71-99.

146. Johnson PTJ, Townsend AR, Cleveland CC, Glibert PM, Howarth RW, Mckenzie VJ, et al. Linking environmental nutrient enrichment and disease emergence in humans and wildlife. Ecol Appl. 2010;20:16-29.

147. Hernandez AD, Bunnell JF, Sukhdeo MVK. Composition and diversity patterns in metazoan parasite communities and anthropogenic disturbance in stream ecosystems. Parasitology. 2007;134:91-102.

148. Feld CK, Birk S, Bradley DC, Hering D, Kail J, Marzin A, et al. From natural to degraded rivers and back again. A test of restoration ecology theory and practice. Adv Ecol Res. 2011;44:119-209.

149. Morley NJ, Lewis JW, Canal UK. Anthropogenic pressure on a molluscantrematode community over a long-term period in the Basingstoke Canal, UK, and its implications for ecosystem health. Ecohealth. 2006;3:269-80.

150. Vidal-Martínez VM. Helminths and protozoans of aquatic organisms as bioindicators of chemical pollution. Parassitologia. 2007;49:177-84.

151. Marcogliese DJ. Interdisciplinarity in marine parasitology. In: Afonso-Dias I, Menezes G, MacKenzie K, Eiras J, editors. Proceedings of the international workshop on marine parasitology: Applied aspects of marine parasitology. Ponta Delgada: University of the Azores; 2008. p. 7-14.

152. Vidal-Martínez VM, Aguirre-Macedo ML, Del Rio-Rodríguez R, Gold-Bouchot G, Rendón-Von Osten J, Miranda-Rosas GA. The pink shrimp Farfantepenaeus duorarum, its symbionts and helminths as bioindicators of chemical pollution in Campeche Sound, Mexico. J Helminthol. 2006;80:159-74.

153. Pech D, Vidal-Martínez VM, Aguirre-Macedo ML, Gold-Bouchot G, HerreraSilveira J, Zapata-Pérez O, et al. The checkered puffer (Spheroides testudineus) and its helminths as bioindicators of chemical pollution in Yucatan coastal lagoons. Sci Total Environ. 2009;407:2315-24.

154. Giraudo M, Bruneau A, Gendron AD, Brodeur P, Pilote M, Marcogliese DJ, et al. Integrated spatial health assessment of yellow perch (Perca flavescens) populations from the St. Lawrence River, Quebec, Canada) part A: physiological parameters and pathogen assessment. Environ Sci Pollut Res. 2016;23:18073-84.

155. Bruneau A, Landry C, Giraudo M, Douville M, Brodeur P, Boily M, et al. Integrated spatial health assessment of yellow perch (Perca flavescens) populations from the St. Lawrence River (QC, Canada), part B: cellular and transcriptomic effects. Environ Sci Pollut Res. 2016;23:18211-21.

156. Marcogliese DJ, Blaise C, Cyr D, de Lafontaine Y, Fournier M, Gagné F, et al. Effects of a major municipal effluent on the St. Lawrence River: A case study. Ambio. 2015:44:257-74.

157. Filipović Marijić V, Vardić Smrzlić I, Raspor B. Does fish reproduction and metabolic activity influence metal levels in fish intestinal parasites, acanthocephalans, during fish spawning and post-spawning period? Chemosphere. 2014;112:449-55.

158. Filipović Marijić V, Vardić Smrzlić I, Raspor B. Effect of acanthocephalan infection on metal, total protein and metallothionein concentrations in European chub from a Sava River section with low metal contamination. Sci Total Environ. 2013;463-464:772-80.

159. Jankovská I, Miholová D, Petrtýl M, Romočuský Š, Kalous L, Vadlejch J, et al. Intestinal parasite Acanthocephalus lucii (Acanthocephala) from European perch (Perca fluviatilis) as a bioindicator for lead pollution in the stream "Jevanský potok" near Prague, Czech Republic. Bull Environ Contam Toxicol. 2011:86:342-6.

160. Brázová T, Torres J, Eira C, Hanzelová V, Miklisová D, Šalamún P. Perch and its parasites as heavy metal biomonitors in a freshwater environment: the case study of the Ružín water reservoir. Slovakia Sensors. 2012;12:3068-81.

161. Jankovská I, Kolihová D, Miholová D, Lukešová D, Romočuský S, Válek P, et al. Effect of Acanthocephalus lucii infection on total mercury concentrations in muscle and gonads of fish host (Perca fluviatilis). Bull Environ Contam Toxicol. 2012;88:967-70 
162. Brázová T, Hanzelová V, Miklisová D, Šalamún P, Vidal-Martínez VM. Host-parasite relationships as determinants of heavy metal concentrations in perch (Perca fluviatilis) and its intestinal parasite infection. Ecotoxicol Environ Saf. 2015;122:551-6.

163. Jankovská I, Miholová D, Lukešová D, Kalous L, Válek P, Romočuský Š, et al. Concentrations of $\mathrm{Zn}, \mathrm{Mn}, \mathrm{Cu}$ and $\mathrm{Cd}$ in different tissues of perch (Perca fluviatilis) and in perch intestinal parasite (Acanthocephalus lucii) from the stream near Prague (Czech Republic). Environ Res. 2012;112:83-5.

164. Paller VGV, Resurreccion DJB, de la Cruz CPP, Bandal MZ. Acanthocephalan parasites (Acanthogyrus sp.) of Nile tilapia (Oreochromis niloticus) as biosink of lead $(\mathrm{Pb})$ contamination in a Philippine freshwater lake. Bull Environ Contam Toxicol. 2016;96:810-5.

165. Teimoori S, Sabour Yaraghi A, Makki MS, Shahbazi F, Nazmara S, Rokni MB, et al. Heavy metal bioabsorption capacity of intestinal helminths in urban rats. Iran J Public Health. 2014;43:310-5.

166. Nachev M, Zimmermann S, Rigaud T, Sures B. Is metal accumulation in Pomphorhynchus laevis dependent on parasite sex or infrapopulation size? Parasitology. 2010;137:1239-48.

167. Baruš V, Šimková A, Prokeš M, Peňáz $M$, Vetešník L. Heavy metals in two host-parasite systems: tapeworm vs. fish. Acta Vet Brno. 2012;81:313-7.

168. Retief N-R, Avenant-Oldewage A, du Preez H. The use of cestode parasites from the largemouth yellowfish, Labeobarbus kimberleyensis (Gilchrist and Thompson, 1913) in the Vaal Dam, South Africa as indicators of heavy metal bioaccumulation. Phys Chem Earth. 2006:31:840-7.

169. Jirsa F, Leodolter-Dvorak M, Krachler R, Frank C. Heavy metals in the nase, Chondrostoma nasus (L. 1758), and its intestinal parasite Caryophyllaeus laticeps (Pallas 1781) from Austrian rivers: Bioindicative aspects. Arch Environ Contam Toxicol. 2008;55:619-26.

170. Torres J, Eira C, Miquel J, Ferrer-Maza D, Delgado E, Casadevall M. Effect of intestinal tapeworm Clestobothrium crassiceps on concentrations of toxic elements and selenium in European hake Merluccius merluccius from the Gulf of Lion (northwestern Mediterranean Sea). J Agric Food Chem. 2015;63:9349-56.

171. Torres J, De Lapuente J, Eira C, Nadal J. Cadmium and lead concentrations in Gallegoide sarfaai (Cestoda: Anoplocephalidae) and Apodemus sylvaticus (Rodentia: Muridae) from Spain. Parasitol Res. 2004;94:468-70.

172. Morris T, Avenant-Oldewage A, Lamberth S, Reed C. Shark parasites as bioindicators of metals in two South African embayments. Mar Pollut Bull. 2016;104:221-8

173. Al-Quraishy S, Gewik MM, Abdel-Baki AAS. The intestinal cestode Hymenolepis diminuta as a lead sink for its rat host in the industrial areas of Riyadh, Saudi Arabia. Saudi J Biol Sci King Saud University. 2014;21:387-90.

174. Čadková Z, Miholová D, Száková J, Válek P, Jankovská I, Langrová I. Is the tapeworm able to affect tissue $\mathrm{Pb}$-concentrations in white rat? Parasitology. 2014;141:826-36.

175. Courtney-Hogue C. Heavy metal accumulation in Lacistorhynchus dollfusi (Trypanorhyncha: Lacistorhynchidae) infecting Citharichthys sordidus (Pleuronectiformes: Bothidae) from Santa Monica Bay, southern California. Parasitology. 2016;143:794-9.

176. Tekin-Özan S, Kir I. Comparative study on the accumulation of heavy metals in different organs of tench (Tinca tinca L. 1758) and plerocercoids of its endoparasite Ligula intestinalis. Parasitol Res. 2005;97:156-9.

177. Tekin-Özan S, Kir I. Concentrations of some heavy metals in tench (Tince tinca L., 1758), its endoparasite (Ligula intestinalis L., 1758), sediment and water in Beysehir Lake, Turkey. Pol J Environ Stud. 2008;17:597-603.

178. Jankovská I, Miholová D, Bejček V, Vadlejch J, Šulc M, Száková J, et al. Influence of parasitism on trace element contents in tissues of Red Fox (Vulpes vulpes) and its parasites Mesocestoides spp. (Cestoda) and Toxascaris leonina (Nematoda). Arch Environ Contam Toxicol. 2010;58:469-77.

179. Jankovská I, Vadlejch J, Száková J, Miholová D, Kunc P, Kní̌ková I, et al. Experimental studies on the lead accumulation in the cestode Moniezia expansa (Cestoda: Anoplocephalidae) and its final host (Ovis aries). Ecotoxicology. 2010;19:928-32.

180. Jankovská I, Vadlejch J, Száková J, Miholová D, Kunc P, Knižková I, et al. Experimental studies on the cadmium accumulation in the cestode Moniezia expansa (Cestoda: Anoplocephalidae) and its final host (Ovis aries). Exp Parasitol. 2010;126:130-4.

181. Eira C, Torres J, Vingada J, Miquel J. Concentration of some toxic elements in Oryctolagus cuniculus and in its intestinal cestode Mosgovoyia ctenoides, in Dunas de Mira (Portugal). Sci Total Environ. 2005;346:81-6.

182. Jankovská I, Miholová D, Langrová I, Bejček V, Vadlejch J, Kolihová D, et al. Influence of parasitism on the use of small terrestrial rodents in environmental pollution monitoring. Environ Pollut. 2009;157:2584-6.
183. Golestaninasab M, Malek M, Roohi A, Karbassi AR, Amoozadeh E, Rashidinejad R, et al. A survey on bioconcentration capacities of some marine parasitic and free-living organisms in the Gulf of Oman. Ecol Indic. 2014:37:99-104.

184. Eira C, Torres J, Miquel J, Vaqueiro J, Soares AMVM, Vingada J. Trace element concentrations in Proteocephalus macrocephalus (Cestoda) and Anguillicola crassus (Nematoda) in comparison to their fish host, Anguilla anguilla in Ria de Aveiro. Portugal Sci Total Environ. 2009;407:991-8.

185. Torres J, Foronda P, Eira C, Miquel J, Feliu C. Trace element concentrations in Raillietina micracantha in comparison to its definitive host, the feral pigeon Columba livia in Santa Cruz de Tenerife (Canary Archipelago, Spain). Arch Environ Contam Toxicol. 2010;58:176-82.

186. Yen Nhi TT, Mohd Shazili NA, Shaharom-Harrison F. Use of cestodes as indicator of heavy-metal pollution. Exp Parasitol. 2013;133:75-9.

187. Torres J, Peig J, Eira C, Borrás M. Cadmium and lead concentrations in Skrjabinotaenia lobata (Cestoda: Catenotaeniidae) and in its host, Apodemus sylvaticus (Rodentia: Muridae) in the urban dumping site of Garraf (Spain). Environ Pollut. 2006;143:4-8.

188. Mendes P. Eira C, Vingada J, Miquel J, Torres J. The system Tetrabothrius bassani (Tetrabothriidae)/Morus bassanus (Sulidae) as a bioindicator of marine heavy metal pollution. Acta Parasitol. 2013;58:21-5.

189. Genc E, Sangun MK, Dural M, Can MF, Altunhan C. Element concentrations in the swimbladder parasite Anguillicola crassus (Nematoda) and its host the European eel, Anguilla anguilla from Asi River (Hatay-Turkey). Environ Monit Assess. 2008;141:59-65.

190. Morsy K, Bashtar A-R, Abdel-Ghaffar F, Mehlhorn H, Quraishy SA, El-Mahdi M, et al. First record of anisakid juveniles (Nematoda) in the European seabass Dicentrarchus labrax (family: Moronidae), and their role as bio-indicators of heavy metal pollution. Parasitol Res. 2012;110:1131-8.

191. Azmat R, Fayyaz S, Kazi N, Mahmood SJ, Uddin F. Natural bioremediation of heavy metals through nematode parasite of fish. Biotechnology. 2008;7: 139-43.

192. Robinson SA, Forbes MR, Hebert CE. Mercury in parasitic nematodes and trematodes and their double-crested cormorant hosts: Bioaccumulation in the face of sequestration by nematodes. Sci Total Environ. 2010;408: 5439-44.

193. Leite LAR, Pedro NHO, Azevedo RKD, Kinoshita A, Gennari RF, Watanabe S, et al. Contracaecum sp. parasitizing Acestrorhynchus lacustris as a bioindicator for metal pollution in the Batalha River, Southeast Brazil. Sci Total Environ. 2017;575:836-40.

194. Khaleghzadeh-Ahangar H, Malek M, McKenzie K. The parasitic nematodes Hysterothylacium sp. type MB larvae as bioindicators of lead and cadmium: A comparative study of parasite and host tissues. Parasitology. 2011;138:1400-5.

195. Dural M, Genc E, Yemenicioǧlu S, Kemal Sangun M. Accumulation of some heavy metals seasonally in Hysterothylacium aduncum (Nematoda) and its host red sea Bream, Pagellus erythrinus (Sparidae) from Gulf of Iskenderun (north-eastern Mediterranean). Bull Environ Contam Toxicol. 2010;84:125-31.

196. Dural M, Genc E, Sangun MK, Güner Ö. Accumulation of some heavy metals in Hysterothylacium aduncum (Nematoda) and its host sea bream, Sparus aurata (Sparidae) from north-eastern Mediterranean Sea (Iskenderun Bay). Environ Monit Assess. 2011;174:147-55.

197. Abdel-Ghaffar F, Abdel-Gaber R, Bashtar A-R, Morsy K, Mehlhorn H, Al Quraishy S, et al. Hysterothylacium aduncum (Nematoda, Anisakidae) with a new host record from the common sole Solea solea (Soleidae) and its role as a biological indicator of pollution. Parasitol Res. 2014;114:513-22.

198. Mazhar R, Shazili NA, Harrison FS. Comparative study of the metal accumulation in Hysterothylacium reliquens (nematode) and Paraphilometroides nemipteri (nematode) as compared with their doubly infected host, Nemipterus peronii (notched threadfin bream). Parasitol Res. 2014;113:3737-43.

199. Baruš V, Jarkovský J, Prokeš M. Philometra ovata (Nematoda: Philometroidea) a potential sentinel species of heavy metal accumulation. Parasitol Res. 2007;100:929-33.

200. Akinsanya B, Kuton MP. Bioaccumulation of heavy metals and parasitic fauna in Synodontis clarias (Linnaeus, 1758) and Chrysichthys nigrodigitatus (Lacepede, 1803) from Lekki Lagoon, Lagos, Nigeria. Asian Pacific J Trop Dis. 2016;6:615-21.

201. Torres J, Kacem H, Eira C, Neifar L, Miquel J. Total mercury and selenium concentrations in Sarpa salpa and Balistes capriscus and in their respective digenean endoparasites Robphildollfusium fractum and Neoapocreadium chabaudi from Tunisia. Acta Parasitol. 2014;59:580-5. 
202. Jankovská I, Sloup V, Száková J, Langrová I, Sloup S. How the tapeworm Hymenolepis diminuta affects zinc and cadmium accumulation in a host fed a hyperaccumulating plant (Arabidopsis halleri). Environ Sci Pollut Res. 2016;23:19126-33.

203. Provencher JF, Braune BM, Gilchrist HG, Forbes MR, Mallory ML. Trace element concentrations and gastrointestinal parasites of Arctic terns breeding in the Canadian High Arctic. Sci Total Env. 2014;476-477:308-16.

204. Hursky O, Pietrock M. Intestinal nematodes affect selenium bioaccumulation, oxidative stress biomarkers, and health parameters in juvenile rainbow trout (Oncorhynchus mykiss). Env Sci Technol. 2015;49:2469-76.

205. Bergey L, Weis JS, Weis P. Mercury uptake by the estuarine species Palaemonetes pugio and Fundulus heteroclitus compared with their parasites, Probopyrus pandalicola and Eustrongylides sp. Mar Poll Bull. 2002;44:1046-50.

206. Evans DW, Irwin SWB, Fitzpatrick S. The effect of digenean (Platyhelminthes) infections on heavy metal concentrations in Littorina littorea. J Mar Biol Assoc UK. 2001;81:349-50.

207. Sures B, Ruchter N, Zimmermann S, Zereini F, Wiseman CLS. Biological effects of PGE on aquatic organisms. In: Zerein F, Wiseman CLS, editors. Platinum metals in the environment. Heidelberg: Springer Berlin Heidelberg; 2015. p. 383-99.

\section{Submit your next manuscript to BioMed Central} and we will help you at every step:

- We accept pre-submission inquiries

- Our selector tool helps you to find the most relevant journal

- We provide round the clock customer support

- Convenient online submission

- Thorough peer review

- Inclusion in PubMed and all major indexing services

- Maximum visibility for your research

Submit your manuscript at www.biomedcentral.com/submit 